\title{
17. LATE NEOGENE TO PLEISTOCENE PALYNOLOGICAL FACIES OF THE PERUVIAN CONTINENTAL MARGIN UPWELLING, LEG $112^{1}$
}

\author{
A. J. Powell, ${ }^{2}$ J. D. Dodge ${ }^{3}$ and Jane Lewis ${ }^{3}$
}

\begin{abstract}
The main objectives of this study are (1) to characterize the spatial and temporal variations in organic matter deposited in upwelling and related sediments (manifest in the palynoclast and organic-walled microplankton assemblages) and (2) to relate these variations to paleoenvironmental changes.

A total of 40 samples from Holes 679D, 680B, 681B, 684B, 686B, and 687B were analyzed. Without exception, amorphogen dominates the palynoclast assemblages overwhelmingly. Influx of terrestrial particulate organic matter to the marine realm was extremely low. Levels of amorphogen swamp other palynoclast categories, and little significance can be attached to any variations observed. Microplankton dominate the palynomorph assemblages, with variable levels of subordinate foraminiferal test linings. Miospores are rare and are absent in most samples. Foraminiferal test linings are particularly abundant in the shallowest samples, which may reflect low surface-water paleotemperatures. Cysts of heterotrophic peridiniacean dinoflagellates (P-cysts) dominate the microplankton assemblages, with variable levels of cysts of autotrophic gonyaulacacean dinoflagellates (G-cysts). Samples dominated by P-cysts are derived largely from laminated, unbioturbated units deposited under the influence of strong upwelling. A lower abundance of P-cysts in some samples is restricted to unlaminated, bioturbated units deposited under oxygenated conditions. We conclude that the ratio of P-cysts to G-cysts is a useful indicator of variable upwelling strength. Detailed study of the variations in the microplankton assemblages offers one the greatest potential for palynological characterization and understanding of the upwelling system.
\end{abstract}

\section{INTRODUCTION}

\section{Background}

During Leg 112 of the Ocean Drilling Program (ODP), 27 holes were drilled at 10 sites on the Peruvian continental margin between $8^{\circ}$ and $14^{\circ} \mathrm{S}$. The location of this area is shown in Figure 1. Drilling took place during November and December 1986.

There were two main objectives for drilling the holes of Leg 112. First, scientists wanted to study the tectonic history of the Andean continental margin since Miocene time, which was predominantly a time of vertical movement with truncation of the continental crust and some accretion at its leading edge. Second, scientists wanted to examine the paleoenvironmental evolution of the forearc basins developed on the margin. Of particular interest was the response of the upwelling regime to changes in global climate and sea levels, as well as to the influence of the local tectonism. Sediments of the forearc basin not only record the influence of vertical tectonic movements but also variations in the strength of the upwelling. Thus, the two main objectives of Leg 112 are closely related.

Information concerning the tectonic setting and upwelling history of the Peruvian continental margin, based upon the preliminary results of Leg 112 , are summarized in studies by Suess et al. (1987) and von Huene et al. (1987).

\section{Scope}

This study is part of the United Kingdom's Natural Environment Research Council (NERC) multidisciplinary, shore-

\footnotetext{
${ }^{1}$ Suess, E., von Huene, R., et al., 1990. Proc. ODP, Sci. Results, 112: College Station, TX (Ocean Drilling Program).

${ }^{2}$ Stratigraphy Branch, BP Research, Chertsey Road, Sunbury-on-Thames, Middlesex, TW16 7LN, United Kingdom. New address: Dinosystems, 6 Combermere Road, London, SW9 9QG, United Kingdom.

${ }^{3}$ Department of Biology, Royal Holloway and Bedford New College, University of London, Egham, Surrey, TW2O OEX, United Kingdom.
}

based project that was established to study the organic record, progress of diagenesis, and other paleoenvironmental problems associated with the Peruvian upwelling system. Despite a high supply of organic matter over the area of offshore Peru, its preservation through space and time is variable. Therefore, the scope of this study covers spatial and temporal variations in acid-resistant organic matter deposited in the upwelling and related sediments of the Peru continental margin and relates these variations to paleoenvironmental changes.

We emphasize that because of processing techniques, the palynological preparations of this study do not represent the total kerogen content of those sediments considered, for two main reasons. First, palynomorphs smaller than $20 \mu \mathrm{m}$, particularly miospores, could not be recovered. Second, much of the amorphogen originally present in the sediments would also have been washed through the sieves.

Samples from six Leg 112 sites were available for study. The locations of these six study sites $(679,680,681,684,686$, and 687) are shown in Figure 2.

\section{Objectives}

This study analyzes the palynological facies of acid-resistant organic matter coarser than $20 \mu \mathrm{m}$. This is the first time that such an approach has been applied in this area. We wished to determine and analyze temporal and spatial variations in the palynoclast, palynomorph, and microplankton assemblages within the upwelling systems along the Peru margin. This is a pilot study that identifies topics worthy of further investigation. Our study is primarily an exploratory one; no attempt has been made to answer specific questions.

\section{METHODS}

\section{Terminology of Palynological Facies}

To avoid any ambiguity and to enhance communications between palynologists and other geoscientists, the use of the palynological facies terminology adopted in this study is discussed. 


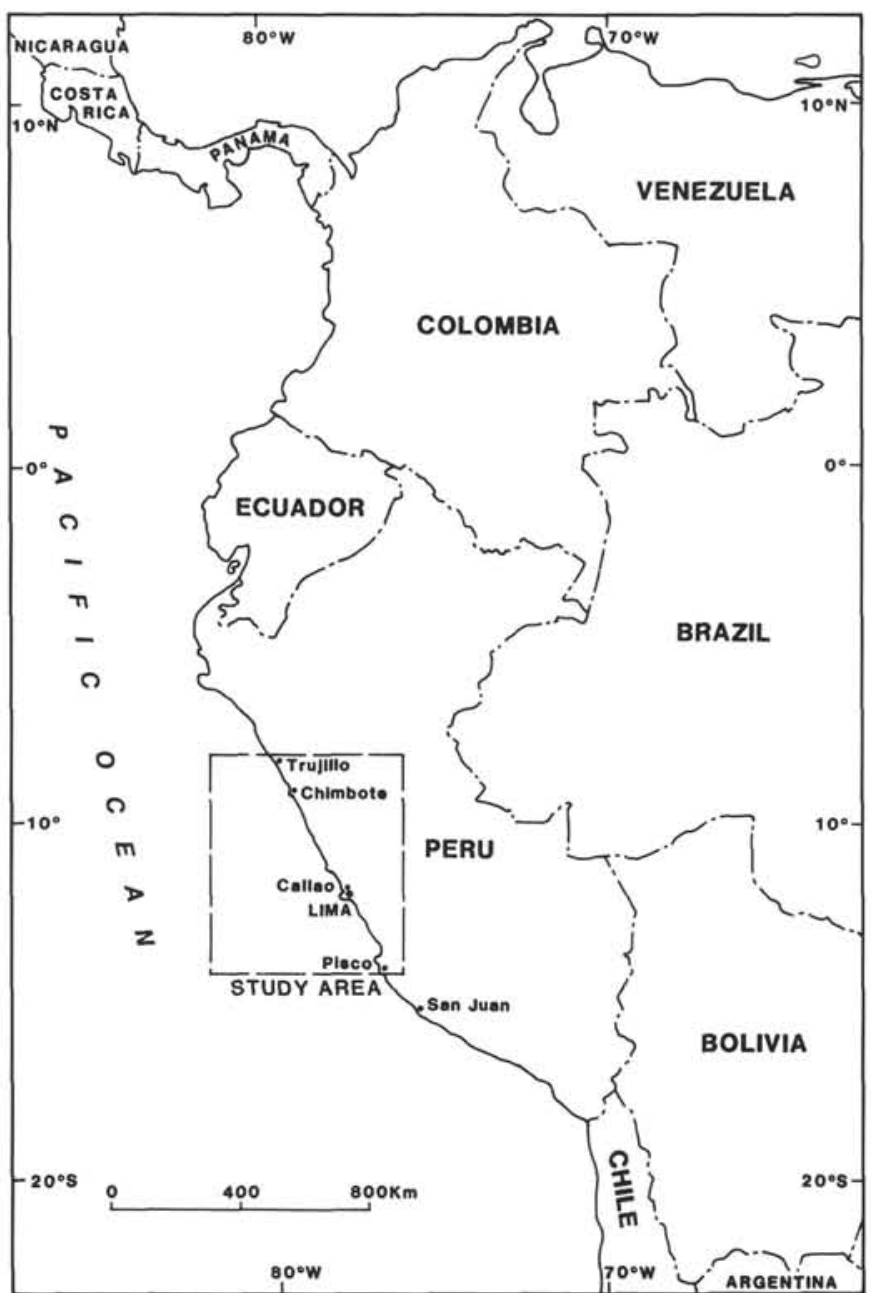

Figure 1. Location of study area offshore Peru.

"Palynoclast" is a new term that has been introduced to encompass all organic components of a palynological preparation. The term "palynoclast" differs from the two similar terms, "palynodebris" and "phytoclast," in two important respects. First, this term recognizes that the organic matter in a palynological assemblage can be of terrigenous origin or of marine origin, or both. Second, it includes amorphogen and phyrogen, as well as hylogen and melanogen. The implication is that all constituents of a palynological assemblage act as sedimentary particles on one scale or another and may undergo diagenetic alteration. The term is broadly similar to Tyson's (1987, Table 2) use of the expression, "Particulate Organic Matter-POM."

Manum (1976, p. 899) used the term palynodebris for ". . . that component of a palynological preparation residue made up of recognizable fragments of plant cuticles and wood tissue or tracheidal matter, whether carbonized (mineral charcoal, fusinite particles) or not." In this original sense, "palynodebris" is synonymous with the term "phytoclast." According to Bostick's (1971, p. 83) definition, phytoclasts are "... grains of solid organic matter dispersed throughout the rock." The terms "palynodebris" and "phytoclast" are not favored here because there was little terrestrial organic influx into the upwelling system offshore Peru; the overwhelming majority of organic grains recorded in this study are of a marine nature, not of land-plant origin.

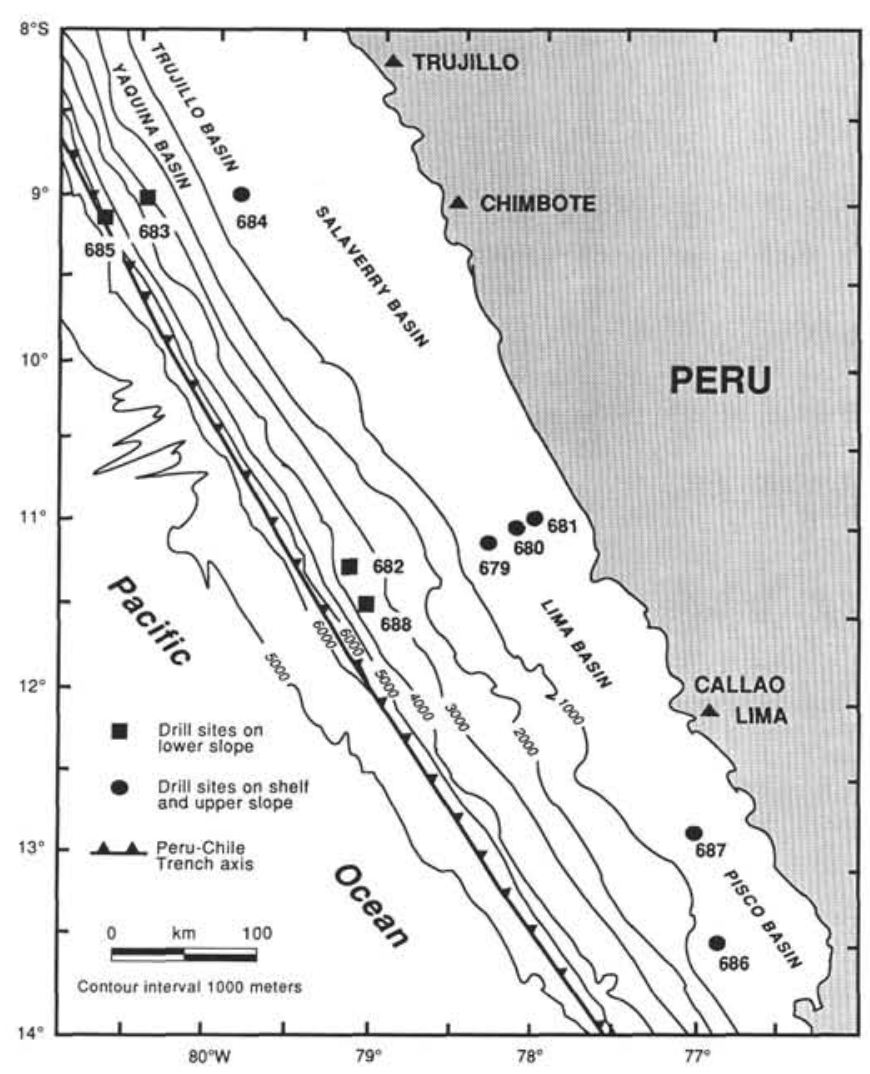

Figure 2. Location of Leg 112 sites offshore Peru.

According to this new terminology, both terrestrial and marine palynomorphs are considered to be palynoclasts. One could, however, argue that this approach is somewhat artificial and simply reflects the accident of resistance to acid treatment during preparation. In this respect, one should remember that, as Bostick $(1971$, p. 84$)$ pointed out, ". . . a phytoclast is defined by the processing that leads to its recovery, rather than by particular origin or structure." This statement applies to any palynoclast and has serious implications for analyses of palynofacies, palynomorph biofacies, and microplankton biofacies.

The term "kerogen" differs from "palynoclast" in that the former represents ". . . sedimentary organic matter insoluble in the usual organic solvents" (Durand, 1980, p. 25). The two terms are not synonymous in all instances, and when, for example, much amorphogen is lost during routine palynological preparation procedures, they may be dramatically different. We think that the term "kerogen" should be avoided when analyzing palynofacies and that its usage should be restricted to the geochemical studies of source potential and maturation. The palynologist can communicate with the geochemist as long as each understands what is meant by "kerogen" and "palynoclast."

Because of the various meanings and interpretations in the literature, it is particularly important to establish what is implied by "palynofacies" and "palynomorph biofacies" and "microplankton biofacies" in this study. From a sedimentological perspective (e.g., Reading, 1978), the definition of a facies clearly should be objective, on the basis of the total observable or measurable nature of the rocks. The implication is that an environmental interpretation will be given to the facies at some stage. Reading (1978, p. 4) stated that "A facies should ideally be a distinctive rock that forms under certain 


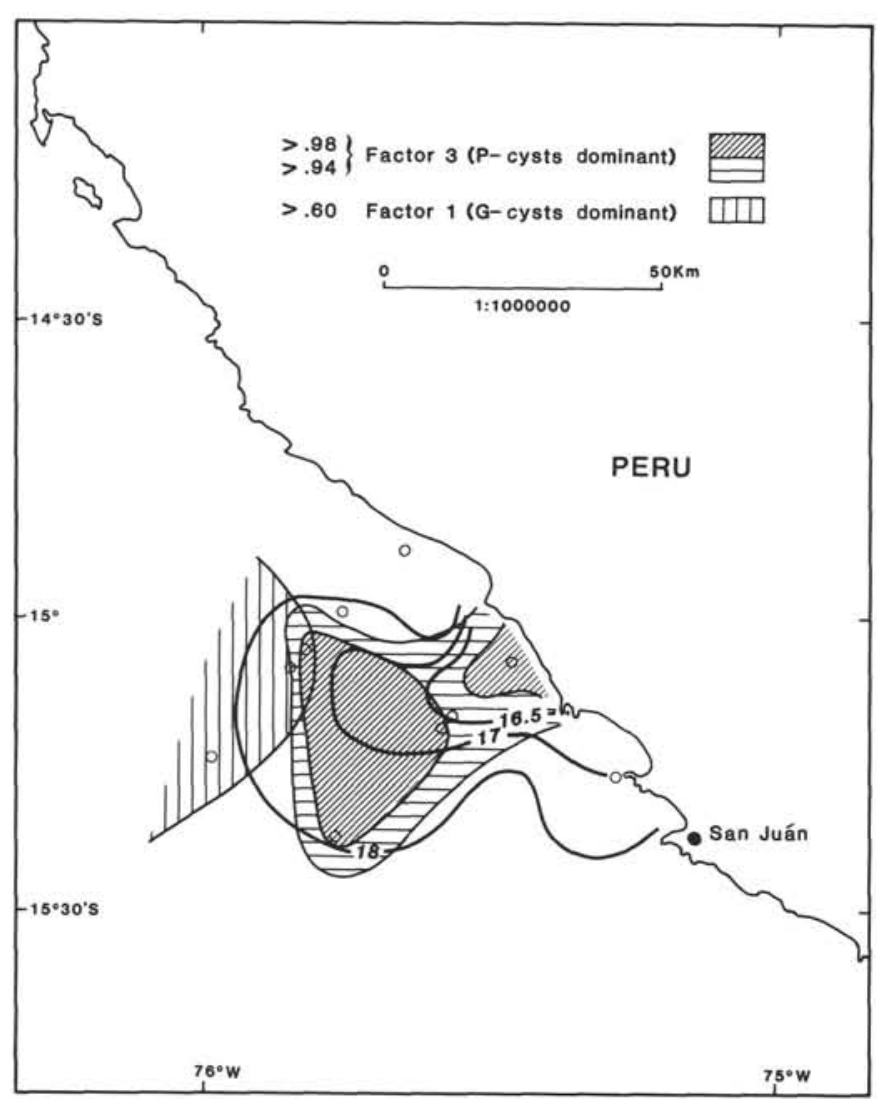

Figure 3. Horizontal variation of dinoflagellate cyst dominance in surface sediments in relation to upwelling. High factor-loading values for factor 3 (P-cysts dominant) correspond with upwelling water; surface-water temperature in ${ }^{\circ} \mathrm{C}$. After Wall et al. (1977, Fig. 21).

conditions of sedimentation, reflecting a particular process or environment."

On this basis and taking into account that palynologists usually observe and measure only a small proportion of a rock, a palynofacies is defined here as a distinctive assemblage of palynoclasts whose composition reflects a particular sedimentary environment.

According to the terminology used here, palynomorphs in general can form an important component of a palynofacies. However, bearing in mind the accident of resistance to acid treatment during preparation, the relationship of palynomorphs, and particularly microplankton, to other palynoclast categories is somewhat artificial. As a result, we think that not only microplankton, but also palynomorphs, should be treated separately, if appropriate. Thus, a palynomorph biofacies can be defined as a distinctive assemblage of palynomorphs whose composition reflects a particular sedimentary environment, and similarly, a microplankton biofacies can be defined as a distinctive assemblage of microplankton whose composition reflects a particular sedimentary environment.

\section{Palynological Information}

Although some information is available concerning modern dinoflagellate populations offshore Peru (e.g., Rojas de Mendiola, 1981), little research has been conducted into the upwelling history of the Peruvian continental margin from a palynological perspective. The only significant published work was undertaken by Wall et al. (1977), who examined the dinoflagellate cyst assemblages from two offshore traverses between Pisco and San Juan (see Figs. 1 and 3) south of our study area. Wall et al.'s major finding (1977) was that a close relationship exists between
Table 1. Samples analyzed in this study, including assigned ages and lithologic units (for further details, see site chapters, Suess, von Huene, et al., 1988).

\begin{tabular}{|c|c|c|c|}
\hline $\begin{array}{l}\text { Core, sample } \\
\text { interval }(\mathrm{cm})\end{array}$ & $\begin{array}{l}\text { Depth } \\
\text { (mbsf) }\end{array}$ & Age & $\begin{array}{c}\text { Lithologic } \\
\text { unit }\end{array}$ \\
\hline $112-679 \mathrm{D}-1 \mathrm{H}-1,25-35$ & 0.25 & Pleistocene & Unit I \\
\hline $1 \mathrm{H}-1,73-83$ & 0.73 & Pleistocene & Unit I \\
\hline $1 \mathrm{H}-2,131-141$ & 2.81 & Pleistocene & Unit I \\
\hline $1 \mathrm{H}-4,88-98$ & 5.38 & Pleistocene & Unit I \\
\hline $2 \mathrm{H}-2,48-58$ & 9.88 & Pleistocene & Unit I \\
\hline $5 \mathrm{H}-2,111-123$ & 39.01 & Pleistocene & Unit I \\
\hline $9 \mathrm{H}-1,59-71$ & 74.99 & Pliocene & Unit II \\
\hline $112-680 \mathrm{~B}-1 \mathrm{H}-1,29-41$ & 0.29 & Pleistocene & Unit I \\
\hline $1 \mathrm{H}-1,70-82$ & 0.70 & Pleistocene & Unit $\mathrm{I}$ \\
\hline $1 \mathrm{H}-4,26-34$ & 4.76 & Pleistocene & Unit I \\
\hline $2 \mathrm{H}-3,29-37$ & 8.79 & Pleistocene & Unit 1 \\
\hline $3 \mathrm{H}-5,129-139$ & 22.29 & Pleistocene & Unit I \\
\hline $10 \mathrm{H}-6,88-100$ & 89.88 & Pliocene & Unit IIIC \\
\hline $112-681 \mathrm{~B}-1 \mathrm{H}-1,36-44$ & 0.36 & Pleistocene & Unit I \\
\hline $1 \mathrm{H}-1,81-89$ & 0.81 & Pleistocene & Unit I \\
\hline $2 \mathrm{H}-2,83-91$ & 8.23 & Pleistocene & Unit I \\
\hline $5 \mathrm{H}-5,57-69$ & 40.97 & Pleistocene & Unit II \\
\hline $10 \mathrm{H}-2,120-131$ & 84.60 & Pleistocene & Unit II \\
\hline $13 X-5,100-112$ & 112.50 & Pleistocene & Unit III \\
\hline $112-684 \mathrm{~B}-1 \mathrm{H}-1,13-24$ & 0.13 & Pleistocene & Unit IA \\
\hline $1 \mathrm{H}-1,63-74$ & 0.63 & Pleistocene & Unit IA \\
\hline $1 \mathrm{H}-3,81-91$ & 3.81 & Pleistocene & Unit IA \\
\hline $1 \mathrm{H}-5,82-94$ & 6.82 & Pleistocene & Unit IA \\
\hline $4 \mathrm{H}-1,117-129$ & 27.67 & Pliocene & Unit III \\
\hline $4 \mathrm{H}-7,11-22$ & 35.61 & Pliocene & Unit III \\
\hline $112-686 \mathrm{~B}-1 \mathrm{H}-1,17-39$ & 0.30 & Pleistocene & Unit I \\
\hline $1 \mathrm{H}-1,87-96$ & 0.87 & Pleistocene & Unit I \\
\hline $1 \mathrm{H}-3,79-89$ & 3.79 & Pleistocene & Unit I \\
\hline $1 \mathrm{H}-5,80-90$ & 6.80 & Pleistocene & Unit 1 \\
\hline $3 \mathrm{H}-2,33-45$ & 19.83 & Pleistocene & Unit I \\
\hline $9 X-5,30-44$ & 80.08 & Pleistocene & Unit II \\
\hline $15 X-5,32-42$ & 138.32 & Pleistocene & Unit III \\
\hline $112-687 \mathrm{~B}-1 \mathrm{H}-1,38-48$ & 0.38 & Pleistocene & Unit IA \\
\hline 1H-1, 79-89 & 0.79 & Pleistocene & Unit IA \\
\hline $1 \mathrm{H}-3,86-98$ & 3.86 & Pleistocene & Unit IA \\
\hline $3 \mathrm{H}-4,38-50$ & 19.58 & Pleistocene & Unit IA \\
\hline $6 \mathrm{H}-3,111-119$ & 47.31 & Pleistocene & Unit IB \\
\hline $7 \mathrm{H}-1,62-73$ & 53.32 & Pleistocene & Unit IB \\
\hline $19 X-3,59-70$ & 160.89 & Pliocene & Unit IIIB \\
\hline
\end{tabular}

dominance within the dinoflagellate cyst assemblages and surface-water temperature (Fig. 3). Thus, assemblages dominated by peridiniacean dinoflagellate cysts are correlated with cooler waters associated with strong upwelling. Conversely, the warmer surface-water temperatures of areas of weaker upwelling are characterized by a greater dominance of gonyaulacacean dinoflagellate cyst species.

\section{Processing Techniques}

In all, 40 (approximately $10 \mathrm{~cm}^{3}$ ) samples from six Leg 112 holes $(679 \mathrm{D}, 680 \mathrm{~B}, 681 \mathrm{~B}, 684 \mathrm{~B}, 686 \mathrm{~B}$, and $687 \mathrm{~B})$ were processed using standard preparation techniques involving sequential treatment with hydrochloric acid $(35.4 \%)$ followed by neutralization, and with hydrofluoric acid $(58 \%-62 \%)$ followed by neutralization. Each residue was split into two equal portions and one half was oxidized for about 1 min using Schulze's solution (a saturated solution of potassium chlorate in nitric acid). Using a $20-\mu \mathrm{m}$ sieve size, two slides (one from the unoxidized residue and another from the oxidized material) were produced for each sample, with glycerine jelly acting as the mounting medium. The effects of oxidation on sample quality and palynomorph recovery are discussed below. Samples are listed in Table 1.

\section{Logging Techniques}

Three detailed data sets (counts of palynoclasts, palynomorphs, and microplankton) were obtained from the unoxi- 
Table 2. Counts of palynoclasts, palynomorphs, and microplankton of studied samples.

\begin{tabular}{|c|c|c|c|c|c|c|c|c|c|c|c|}
\hline \multirow{2}{*}{$\begin{array}{l}\text { Core, section } \\
\text { interval }(\mathrm{cm})\end{array}$} & \multicolumn{3}{|c|}{ Palynoclasts } & \multicolumn{3}{|c|}{ Palynomorphs } & \multicolumn{4}{|c|}{ Microplankton } & \multirow[b]{2}{*}{$\mathrm{n}$} \\
\hline & AMO & PAL & $\mathrm{n}$ & MIC & FOR & $\mathrm{n}$ & PER & SKO & SPI & ACR & \\
\hline $112-679 \mathrm{D}-1 \mathrm{H}-1,25-35$ & 296 & 004 & 300 & 065 & 135 & 200 & 096 & 003 & 001 & 000 & 100 \\
\hline $1 \mathrm{H}-1,73-83$ & 295 & 005 & 300 & 131 & 069 & 200 & 119 & 002 & 079 & 000 & 200 \\
\hline $1 \mathrm{H}-2,131-141$ & 296 & 004 & 300 & 132 & 068 & 200 & 180 & 001 & 019 & 000 & 200 \\
\hline $1 \mathrm{H}-4,88-98$ & 292 & 008 & 300 & 202 & 098 & 300 & 243 & 017 & 040 & 000 & 300 \\
\hline $2 \mathrm{H}-2,48-58$ & 295 & 005 & 300 & 144 & 156 & 300 & 183 & 000 & 017 & 000 & 200 \\
\hline $5 \mathrm{H}-2,111-123$ & 286 & 014 & 300 & 235 & 065 & 300 & 291 & 006 & 000 & 003 & 300 \\
\hline $9 \mathrm{H}-1,59-71$ & 295 & 005 & 300 & 137 & 163 & 300 & 175 & 005 & 017 & 003 & 200 \\
\hline $112-680 \mathrm{~B}-1 \mathrm{H}-1,29-41$ & 296 & 004 & 300 & 224 & 076 & 300 & 270 & 016 & 012 & 002 & 300 \\
\hline $1 \mathrm{H}-1,70-82$ & 291 & 009 & 300 & 224 & 076 & 300 & 256 & 033 & 005 & 006 & 300 \\
\hline $1 \mathrm{H}-4,26-34$ & 292 & 008 & 300 & 246 & 054 & 300 & 202 & 012 & 085 & 001 & 300 \\
\hline $2 \mathrm{H}-3,29-37$ & 297 & 003 & 300 & 289 & 011 & 300 & 281 & 000 & 019 & 000 & 300 \\
\hline $3 \mathrm{H}-5,129-139$ & 298 & 002 & 300 & 292 & 008 & 300 & 215 & 021 & 064 & 000 & 300 \\
\hline $10 \mathrm{H}-6,88-100$ & 237 & 063 & 300 & 284 & 016 & 300 & 146 & 061 & 093 & 000 & 300 \\
\hline 112-681B-1H-1, 36-44 & 296 & 004 & 300 & 073 & 027 & 100 & 097 & 002 & 001 & 000 & 100 \\
\hline $1 \mathrm{H}-1,81-89$ & 298 & 002 & 300 & 074 & 026 & 100 & 097 & 002 & 001 & 000 & 100 \\
\hline $2 \mathrm{H}-2,83-91$ & 292 & 008 & 300 & 268 & 032 & 300 & 274 & 005 & 019 & 002 & 300 \\
\hline $2 \mathrm{H}-5,34-42$ & 268 & 032 & 300 & 253 & 047 & 300 & 235 & 016 & 044 & 005 & 300 \\
\hline $5 \mathrm{H}-5,57-69$ & 292 & 008 & 300 & 238 & 062 & 300 & 286 & 001 & 009 & 004 & 300 \\
\hline $10 \mathrm{H}-2,120-131$ & 296 & 004 & 300 & 149 & 051 & 200 & 194 & 000 & 001 & 005 & 200 \\
\hline $13 X-5,100-112$ & 292 & 008 & 300 & 250 & 050 & 300 & 278 & 002 & 008 & 012 & 300 \\
\hline $112-684 \mathrm{~B}-1 \mathrm{H}-1,13-24$ & 293 & 007 & 300 & 112 & 088 & 200 & 164 & 025 & 009 & 002 & 200 \\
\hline $1 \mathrm{H}-1,63-74$ & 294 & 006 & 300 & 185 & 115 & 300 & 154 & 036 & 006 & 004 & 200 \\
\hline $1 \mathrm{H}-3,81-91$ & 297 & 003 & 300 & 208 & 092 & 300 & 259 & 004 & 007 & 030 & 300 \\
\hline $1 \mathrm{H}-5,82-94$ & 291 & 009 & 300 & 183 & 117 & 300 & 198 & 001 & 001 & 000 & 200 \\
\hline $4 \mathrm{H}-1,117-129$ & 294 & 006 & 300 & 199 & 101 & 300 & 193 & 038 & 064 & 005 & 300 \\
\hline $4 \mathrm{H}-7,11-12$ & 298 & 002 & 300 & 181 & 019 & 200 & 073 & 008 & 113 & 006 & 200 \\
\hline $112-686 \mathrm{~B}-1 \mathrm{H}-1,17-39$ & 291 & 009 & 300 & 201 & 099 & 300 & 236 & 009 & 052 & 003 & 300 \\
\hline $1 \mathrm{H}-1,87-96$ & 255 & 045 & 300 & 150 & 150 & 300 & 188 & 027 & 078 & 007 & 300 \\
\hline $1 \mathrm{H}-3,79-89$ & 292 & 008 & 300 & 226 & 074 & 300 & 292 & 006 & 002 & 000 & 300 \\
\hline $1 \mathrm{H}-5,80-90$ & 285 & 015 & 300 & 180 & 120 & 300 & 237 & 005 & 055 & 003 & 300 \\
\hline $3 \mathrm{H}-2,33-45$ & 283 & 017 & 300 & 282 & 018 & 300 & 255 & 011 & 031 & 003 & 300 \\
\hline $9 \mathrm{X}-5,30-44$ & 290 & 010 & 300 & 251 & 049 & 300 & 166 & 008 & 126 & 000 & 300 \\
\hline $15 X-5,32-42$ & 299 & 001 & 300 & 271 & 029 & 300 & 271 & 018 & 010 & 001 & 300 \\
\hline $112-687 \mathrm{~B}-1 \mathrm{H}-1,38-48$ & 286 & 014 & 300 & 214 & 086 & 300 & 262 & 021 & 011 & 006 & 300 \\
\hline $1 \mathrm{H}-1,79-89$ & 296 & 004 & 300 & 229 & 071 & 300 & 265 & 030 & 003 & 002 & 300 \\
\hline $1 \mathrm{H}-3,86-98$ & 289 & 011 & 300 & 282 & 018 & 300 & 210 & 003 & 046 & 041 & 300 \\
\hline $3 \mathrm{H}-4,38-50$ & 290 & 010 & 300 & 290 & 010 & 300 & 225 & 008 & 003 & 064 & 300 \\
\hline $6 \mathrm{H}-3,111-119$ & 288 & 012 & 300 & 236 & 064 & 300 & 266 & 001 & 002 & 031 & 300 \\
\hline $7 \mathrm{H}-1,62-73$ & 297 & 003 & 300 & 201 & 099 & 300 & 182 & 004 & 002 & 012 & 200 \\
\hline $19 X-3,59-70$ & 289 & 011 & 300 & 231 & 069 & 300 & 275 & 010 & 000 & 015 & 300 \\
\hline
\end{tabular}

$\mathrm{AMO}=$ amorphogen $; \mathrm{PAL}=$ palynomorphs $; \mathrm{MIC}=$ microplankton $; \mathrm{FOR}=$ foraminiferal test linings $; \mathrm{PER}=$ peridiniacean dinoflagellate cysts (P-cysts); SKO = skolochorate dinoflagellate cysts (G-cysts); SPI = spiniferate dinoflagellate cysts (G-cysts); $\mathrm{ACR}=$ acritarchs; and $\mathrm{n}=$ population of count.

dized material. In the first case, individual palynoclasts were counted within fields of view at the same set of predetermined locations on each slide until 300 grains had been counted. Any fine disseminated material not removed by the filtering procedure was ignored. Following this, traverses were conducted on each slide until either 300 palynomorph specimens had been encountered or until the whole slide had been traversed, whichever came first. Only foraminiferal test linings having six or more chambers were counted, a procedure adopted by Traverse and Ginsburg (1966). If possible, the counts were continued in a similar fashion until 300 microplankton specimens had been recorded.

The oxidized slides were studied in detail separately for their dinoflagellate cyst content. Species lists were obtained for the samples in question. The reliability of the data obtained was tested and is discussed in the section on "Quality Control of Data" (this chapter).

\section{Presentation of Data}

Percentages of the major palynoclast, palynomorph, and microplankton categories were calculated for each sample according to the three groups of data collected. These counts and relative abundances are given in Tables 2 and 3, respectively.

The following log ratios (the common logarithms, base 10) were calculated from the abundances: (1) AMO/PAL (amor- phogen/palynomorphs) log ratio; (2) MIC/FOR (microplankton/foraminiferal test linings) log ratio ; (3) PER/CHO (peridiniacean/chorate dinoflagellate cysts $=$ P-cyst/G-cyst) $\log$ ratio. The calculations of $X / Y$ show that when $X=Y$, the log ratio is 0 ; when $X>Y$, the $\log$ ratio is $>0$ (positive values); when $X<Y$, the $\log$ ratio is $<0$ (negative values). The value for each log ratio is given in Table 4.

\section{Quality Control of Data}

To have maximum confidence in these data, we had to establish the quality and consistency of sample preparation and the reliability of our methods of data acquisition. To do this, a single operator (A. J. Powell) analyzed preparations of samples from Hole 686B that were both unoxidized and oxidized. For each sample, one slide was logged from an unoxidized residue and one from an oxidized one. If possible, 300 microplankton specimens were counted by traversing each slide at predetermined coordinates. The abundances of the four major microplankton categories for the unoxidized and oxidized preparations were calculated and are given in Table 5 .

On average, oxidation slightly enhances the recovery of spiniferate dinoflagellate cysts with levels of peridiniacean and skolochorate dinoflagellates cysts reduced in abundance. However, differences are small and may be explained by the fact that oxidation cleans the residue of amorphogen, which, 
Table 3. Relative abundances of palynoclasts, palynomorphs, and microplankton of studied samples.

\begin{tabular}{|c|c|c|c|c|c|c|c|c|}
\hline \multirow{2}{*}{$\begin{array}{l}\text { Core, section } \\
\text { interval }(\mathrm{cm})\end{array}$} & \multicolumn{2}{|c|}{ Palynoclasts } & \multicolumn{2}{|c|}{ Palynomorphs } & \multicolumn{4}{|c|}{ Microplankton } \\
\hline & AMO & PAL & MIC & FOR & PER & SKO & SPI & ACR \\
\hline $112-679 \mathrm{D}-1 \mathrm{H}-1,25-35$ & 98.5 & 01.5 & 32.5 & 67.5 & 96.0 & 03.0 & 01.0 & 00.0 \\
\hline $1 \mathrm{H}-1,73-83$ & 98.5 & 01.5 & 65.5 & 34.5 & 59.5 & 01.0 & 39.5 & 00.0 \\
\hline $1 \mathrm{H}-2,131-141$ & 98.5 & 01.5 & 66.0 & 34.0 & 89.5 & 01.0 & 09.5 & 00.0 \\
\hline $1 \mathrm{H}-4,88-98$ & 97.5 & 02.5 & 67.5 & 32.5 & 81.0 & 05.5 & 13.5 & 00.0 \\
\hline $2 \mathrm{H}-2,48-58$ & 98.5 & 01.5 & 48.0 & 52.0 & 91.5 & 00.0 & 08.5 & 00.0 \\
\hline $5 \mathrm{H}-2,111-123$ & 95.5 & 04.5 & 78.5 & 21.5 & 97.0 & 02.0 & 00.0 & 01.0 \\
\hline $9 \mathrm{H}-1,59-71$ & 98.5 & 01.5 & 45.5 & 54.5 & 87.5 & 02.5 & 08.5 & 01.5 \\
\hline Mean $(n=7)$ & 98.0 & 02.0 & 57.5 & 42.5 & 86.0 & 02.0 & 11.5 & 00.5 \\
\hline $112-680 \mathrm{~B}-1 \mathrm{H}-1,29-41$ & 98.5 & 01.5 & 74.5 & 25.5 & 90.0 & 05.5 & 04.0 & 00.5 \\
\hline $1 \mathrm{H}-1,70-82$ & 97.0 & 03.0 & 74.5 & 25.5 & 85.5 & 11.0 & 01.5 & 02.0 \\
\hline $1 \mathrm{H}-4,26-34$ & 97.5 & 02.5 & 82.0 & 18.0 & 67.0 & 04.0 & 28.5 & 00.5 \\
\hline $2 \mathrm{H}-3,29-37$ & 99.0 & 01.0 & 96.5 & 03.5 & 93.5 & 00.0 & 06.5 & 00.0 \\
\hline $3 \mathrm{H}-5,129-139$ & 99.5 & 00.5 & 97.5 & 02.5 & 71.5 & 07.0 & 21.5 & 00.0 \\
\hline $10 \mathrm{H}-6,88-100$ & 79.0 & 21.0 & 94.5 & 05.5 & 48.5 & 20.5 & 31.0 & 00.0 \\
\hline Mean $(n=6)$ & 95.0 & 05.0 & 86.5 & 13.5 & 76.0 & 08.0 & 15.5 & 00.5 \\
\hline $112-681 \mathrm{~B}-1 \mathrm{H}-1,36-44$ & 98.5 & 01.5 & 73.0 & 27.0 & 97.0 & 02.0 & 01.0 & 00.0 \\
\hline $1 \mathrm{H}-1,81-89$ & 99.5 & 00.5 & 74.0 & 26.0 & 97.0 & 02.0 & 01.0 & 00.0 \\
\hline $2 \mathrm{H}-2,83-91$ & 97.5 & 02.5 & 89.5 & 10.5 & 91.5 & 01.5 & 06.5 & 00.5 \\
\hline $2 \mathrm{H}-5,34-42$ & 89.5 & 10.5 & 84.5 & 15.5 & 78.5 & 05.5 & 14.5 & 01.5 \\
\hline $5 \mathrm{H}-5,57-69$ & 97.5 & 02.5 & 79.5 & 20.5 & 95.0 & 00.5 & 03.0 & 01.5 \\
\hline $10 \mathrm{H}-2,120-131$ & 98.5 & 01.5 & 74.5 & 25.5 & 97.0 & 00.0 & 00.5 & 02.5 \\
\hline $13 X-5,100-112$ & 97.5 & 02.5 & 83.5 & 16.5 & 93.0 & 00.5 & 02.5 & 04.0 \\
\hline Mean $(\mathrm{n}=7)$ & 97.0 & 03.0 & 80.0 & 20.0 & 93.0 & 01.5 & 04.0 & 01.5 \\
\hline $112-684 \mathrm{~B}-1 \mathrm{H}-1,13-24$ & 97.5 & 02.5 & 56.0 & 44.0 & 82.0 & 12.5 & 04.5 & 01.0 \\
\hline $1 \mathrm{H}-1,63-74$ & 98.0 & 02.0 & 61.5 & 38.5 & 77.0 & 18.0 & 03.0 & 02.0 \\
\hline $1 \mathrm{H}-3,81-91$ & 99.0 & 01.0 & 69.5 & 30.5 & 86.0 & 01.5 & 02.5 & 10.0 \\
\hline $1 \mathrm{H}-5,82-94$ & 97.0 & 03.0 & 61.0 & 39.0 & 99.0 & 00.5 & 00.5 & 00.0 \\
\hline $4 \mathrm{H}-1,117-129$ & 98.0 & 02.0 & 66.5 & 33.5 & 64.5 & 12.5 & 21.5 & 01.5 \\
\hline $4 \mathrm{H}-7,11-22$ & 99.5 & 00.5 & 90.5 & 09.5 & 36.5 & 04.0 & 56.5 & 03.0 \\
\hline Mean $(\mathrm{n}=6)$ & 98.0 & 02.0 & 67.5 & 32.5 & 74.0 & 08.0 & 15.0 & 03.0 \\
\hline $112-686 \mathrm{~B}-1 \mathrm{H}-1,17-39$ & 97.0 & 03.0 & 67.0 & 33.0 & 78.5 & 03.0 & 17.5 & 01.0 \\
\hline $1 \mathrm{H}-1,87-96$ & 85.0 & 15.0 & 50.0 & 50.0 & 62.5 & 09.0 & 26.0 & 02.5 \\
\hline $1 \mathrm{H}-3,79-89$ & 97.5 & 02.5 & 75.5 & 24.5 & 97.5 & 02.0 & 00.5 & 00.0 \\
\hline $1 \mathrm{H}-5,80-90$ & 95.0 & 05.0 & 60.0 & 40.0 & 79.0 & 01.5 & 18.5 & 01.0 \\
\hline $3 \mathrm{H}-2,33-45$ & 94.5 & 05.5 & 94.0 & 06.0 & 85.0 & 03.5 & 10.5 & 01.0 \\
\hline $9 X-5,30-44$ & 96.5 & 03.5 & 83.5 & 16.5 & 55.5 & 02.5 & 42.0 & 00.0 \\
\hline $15 X-5,32-42$ & 99.5 & 00.5 & 90.5 & 09.5 & 90.0 & 06.0 & 03.5 & 00.5 \\
\hline Mean $(n=7)$ & 95.0 & 05.0 & 74.5 & 25.5 & 78.0 & 04.0 & 17.0 & 01.0 \\
\hline $112-687 \mathrm{~B}-1 \mathrm{H}-1,38-48$ & 95.5 & 04.5 & 71.5 & 28.5 & 87.5 & 07.0 & 03.5 & 02.0 \\
\hline $1 \mathrm{H}-1,79-89$ & 98.5 & 01.5 & 76.5 & 23.5 & 88.5 & 10.0 & 01.0 & 00.5 \\
\hline $1 \mathrm{H}-3,86-98$ & 96.5 & 03.5 & 94.0 & 06.0 & 70.0 & 01.0 & 15.5 & 13.5 \\
\hline $3 \mathrm{H}-4,38-50$ & 96.5 & 03.5 & 96.5 & 03.5 & 75.0 & 02.5 & 01.0 & 21.5 \\
\hline $6 \mathrm{H}-3,111-119$ & 96.0 & 04.0 & 78.5 & 21.5 & 88.5 & 00.5 & 00.5 & 10.5 \\
\hline $7 \mathrm{H}-1,62-73$ & 99.0 & 01.0 & 67.0 & 33.0 & 91.0 & 02.0 & 01.0 & 06.0 \\
\hline $19 X-3,59-70$ & 96.5 & 03.5 & 77.0 & 23.0 & 91.5 & 03.5 & 00.0 & 05.0 \\
\hline Mean $(\mathrm{n}=7)$ & 97.0 & 03.0 & 74.0 & 26.0 & 82.0 & 04.5 & 11.0 & 02.5 \\
\hline Grand mean $(n=40)$ & 96.5 & 03.5 & 73.5 & 26.5 & 81.5 & 04.5 & 12.5 & 01.5 \\
\hline
\end{tabular}

$\mathrm{AMO}=$ amorphogen $; \mathrm{PAL}=$ palynomorphs $; \mathrm{MIC}=$ microplankton $; \mathrm{FOR}=$ foraminiferal test linings $\mathrm{PER}=$ peridiniacean dinoflagellate cysts (P-cysts); $\mathrm{SKO}=$ skolochorate dinoflagellate cysts (G-cysts) $\mathrm{SPI}=$ spiniferate dinoflagellate cysts $(\mathrm{G}$-cysts); $\mathrm{ACR}=$ acritarchs.

in unoxidized preparations, often adheres to the barbed processes of spiniferate cysts, thus tending to obscure some individuals. Interestingly, the effects of oxidation do not seem to have destroyed many peridiniacean cysts. Strong evidence exists (e.g., Dale, 1976) to suggest that vigorous acid treatment destroys the more delicate cysts, particularly peridiniacean forms. If any P-cysts were lost to the microplankton assemblages used in this study, these probably disintegrated or were destroyed before oxidation procedures took place.

Here, we also observe that besides reducing the quantities of amorphogen in the preparations, oxidation also reduces the levels of foraminiferal test linings, presumably by detaching individual chambers, which then pass through the sieve mesh. Traverse and Ginsburg (1966, p. 439) noted that foraminiferal tests linings "... have a tendency to break down into fragments, so that single chambers or units of $1-2+$ chambers are often seen."
The results of this check for quality control of data also demonstrate the consistency of data acquisition. As a result, one can assume fairly safely that data were collected in as consistent a fashion as possible.

\section{PALYNOLOGICAL FACIES ANALYSIS}

\section{Hole 679D Palynofacies, Palynomorph, and Microplankton Biofacies}

\section{Hole 679D Location and Samples}

Hole $679 \mathrm{D}$ is located at $11^{\circ} 03.83^{\prime} \mathrm{S}, 78^{\circ} 16.33^{\prime} \mathrm{W}$, at a water depth of $439.5 \mathrm{~m}$. This hole reached a total depth of 245.40 meters below seafloor (mbsf). Seven palynological preparations were analyzed from Hole 679D (Figs. 4 through 6). Samples at $0.25,0.73,2.81,5.38,9.88$, and $39.01 \mathrm{mbsf}$ are of Pleistocene age, while the sample at 74.99 mbsf is of Pliocene 
Table 4. Palynoclast, palynomorph, and microplankton log ratios of studied samples.

\begin{tabular}{|c|c|c|c|}
\hline $\begin{array}{l}\text { Core, sample, } \\
\text { interval }(\mathrm{cm})\end{array}$ & $\begin{array}{c}\text { Palynoclasts } \\
\text { AMO/PAL }\end{array}$ & $\begin{array}{l}\text { Palynomorphs } \\
\text { MIC/FOR }\end{array}$ & $\begin{array}{c}\text { Microplankton } \\
\text { PER/CHO }\end{array}$ \\
\hline 112-679D-1H-1, 25-35 & 1.87 & -0.32 & 1.38 \\
\hline $1 \mathrm{H}-1,73-83$ & 1.77 & 0.28 & 0.17 \\
\hline $1 \mathrm{H}-2,131-141$ & 1.87 & 0.29 & 0.95 \\
\hline $1 \mathrm{H}-4,88-98$ & 1.56 & 0.31 & 0.63 \\
\hline $2 \mathrm{H}-2,48-58$ & 1.77 & -0.03 & 1.03 \\
\hline $5 \mathrm{H}-2,111-123$ & 1.31 & 0.56 & 1.69 \\
\hline $9 \mathrm{H}-1,59-71$ & 1.77 & -0.07 & 0.90 \\
\hline Mean $(n=7)$ & 1.70 & 0.15 & 0.96 \\
\hline 112-680B-1H-1, 29-41 & 1.87 & 0.47 & 0.98 \\
\hline 1H-1, 70-82 & 1.51 & 0.47 & 0.83 \\
\hline $1 \mathrm{H}-4,26-34$ & 1.56 & 0.66 & 0.32 \\
\hline $2 \mathrm{H}-3,29-37$ & 2.00 & 1.42 & 1.17 \\
\hline $3 \mathrm{H}-5,129-139$ & 2.17 & 1.50 & 0.40 \\
\hline $10 \mathrm{H}-6,88-100$ & 0.57 & 1.25 & -0.02 \\
\hline Mean $(n=6)$ & 1.61 & 0.97 & 0.61 \\
\hline $112-681 \mathrm{~B}-1 \mathrm{H}-1,36-44$ & 1.87 & 0.43 & 1.51 \\
\hline $1 \mathrm{H}-1,81-89$ & 2.17 & 0.45 & 1.51 \\
\hline $2 \mathrm{H}-2,83-91$ & 1.56 & 0.92 & 1.06 \\
\hline $2 \mathrm{H}-5,34-42$ & 0.92 & 0.73 & 0.59 \\
\hline $5 \mathrm{H}-5,57-69$ & 1.56 & 0.58 & 1.46 \\
\hline $10 \mathrm{H}-2,120-131$ & 1.87 & 0.46 & 2.29 \\
\hline $13 X-5,100-112$ & 1.56 & 0.70 & 1.44 \\
\hline Mean $(n=7)$ & 1.64 & 0.61 & 1.41 \\
\hline $112-684 \mathrm{~B}-1 \mathrm{H}-1,13-24$ & 1.62 & 0.10 & 0.68 \\
\hline $1 \mathrm{H}-1,63-74$ & 1.69 & 0.21 & 0.56 \\
\hline $1 \mathrm{H}-3,81-91$ & 2.00 & 0.35 & 1.37 \\
\hline IH-5, 82-94 & 1.51 & 0.19 & 2.00 \\
\hline $4 H-1,117-129$ & 1.69 & 0.29 & 0.28 \\
\hline $4 \mathrm{H}-7,11-22$ & 2.17 & 0.98 & -0.22 \\
\hline Mean $(n=6)$ & 1.78 & 0.35 & 0.78 \\
\hline $112-686 \mathrm{~B}-1 \mathrm{H}-1,17-39$ & 1.51 & 0.31 & 0.59 \\
\hline $1 \mathrm{H}-1,87-96$ & 0.75 & 0.00 & 0.25 \\
\hline $1 \mathrm{H}-3,79-89$ & 1.56 & 0.48 & 1.56 \\
\hline $1 \mathrm{H}-5,80-90$ & 1.28 & 0.18 & 0.60 \\
\hline $3 \mathrm{H}-2,33-45$ & 1.22 & 1.19 & 0.78 \\
\hline $9 X-5,30-44$ & 1.46 & 0.71 & 0.09 \\
\hline $15 X-5,32-42$ & 2.48 & 0.97 & 0.99 \\
\hline Mean $(n=7)$ & 1.47 & 0.55 & 0.69 \\
\hline $112-687 \mathrm{~B}-1 \mathrm{H}-1,38-48$ & 1.31 & 0.40 & 0.91 \\
\hline $1 \mathrm{H}-1,79-89$ & 1.87 & 0.51 & 0.90 \\
\hline $1 \mathrm{H}-3,86-98$ & 1.42 & 1.19 & 0.63 \\
\hline $3 \mathrm{H}-4,38-50$ & 1.46 & 1.46 & 1.31 \\
\hline $6 \mathrm{H}-3,111-119$ & 1.38 & 0.57 & 1.95 \\
\hline $7 \mathrm{H}-1,62-73$ & 2.00 & 0.31 & 1.48 \\
\hline $19 X-3,59-70$ & 1.42 & 0.52 & 1.44 \\
\hline Mean $(n=7)$ & 1.55 & 0.71 & 1.23 \\
\hline Grand mean $(n=40)$ & 1.62 & 0.55 & 0.96 \\
\hline
\end{tabular}

$\mathrm{AMO} / \mathrm{PAL}=$ amorphogen/palynomorphs $\log$ ratio $; \mathrm{MIC} / \mathrm{FOR}=$ microplankton/ foraminiferal test linings $\log$ ratio; $\mathrm{PER} / \mathrm{CHO}=$ peridiniacean/chorate dinoflagellate cysts (= P-cysts/G-cysts) log ratio.

age. Samples at $0.25,0.73,2.81,5.38,9.88$ and $39.01 \mathrm{mbsf}$ are from lithologic Unit I (olive to dark gray diatomaceous foraminiferal mud with sporadic ash layers); and the sample at $74.99 \mathrm{mbsf}$ is from lithologic Unit II (olive to black diatomaceous mud with ash layers).

\section{Hole 679D Palynofacies}

The palynoclast assemblages are dominated by amorphogen with a mean value of $98.0 \%$. Vertical variations in the levels of amorphogen and palynomorphs are shown in Figure 4. A slight increase in the level of palynomorphs (4.5\%) was identified at 39.01 mbsf toward the base of lithologic Unit I. This minor deviation is demonstrated more clearly by the stratigraphical variations in the AMO/PAL (amorphogen/ palynomorphs) log ratio, as illustrated in Figure 5.

One can attach little paleoenvironmental significance to the semiquantitative trends observed in the scattered samples used in this pilot study.

\section{Hole 679D Palynomorph Biofacies}

In contrast to the palynoclast assemblages, levels of microplankton and foraminiferal test linings vary more within the sample suite analyzed (Fig. 4). On average, microplankton account for $57.5 \%$ of the population, and foraminiferal test linings account for $42.5 \%$. Thus, foraminiferal test linings are well represented when compared with the other Leg 112 holes studied. These attain a minimum level at $39.01 \mathrm{mbsf}$ (the depth at which there is a slight peak in the occurrence of palynomorphs with respect to amorphogen) and are particularly abundant $(67.5 \%)$ in the uppermost sample at 0.25 mbsf. These trends are best illustrated in Figure 5, in which the microplankton/foraminiferal test linings (MIC/FOR) log ratio can be seen to lie near the zero (i.e., 50:50) level.

The high abundance of foraminiferal test linings relative to the numbers of microplankton may be an indirect reflection of sedimentation associated with an anoxic bottom environment (lithologic Unit I: middle to upper bathyal water depths) or a dysaerobic environment (lithologic Unit II: upper bathyal water depths).

\section{Hole 679D Microplankton Biofacies}

The stratigraphic distribution of the dinoflagellate cyst species appearing in samples from Hole 679D is summarized in Table 6. Peridiniacean dinoflagellate cysts (P-cysts) dominate the microplankton assemblages with a mean value of $86.0 \%$ (Fig. 6). Of the species occurring, Brigantedinium spp. dominate the assemblages. The gonyaulacacean dinoflagellate cysts (G-cysts) are represented by Spiniferites ramosus (notably at $0.73 \mathrm{mbsf}$ ), with lesser amounts of Operculodinium centrocarpum and Nematosphaeropsis labyrinthea (the latter also are common at $0.73 \mathrm{mbsf}$ ).

The downhole variations in the PER/CHO (peridiniacean/ chorate dinoflagellate cysts $=$ P-cysts/G-cysts) $\log$ ratio are shown in Figure 5. The peak in the abundance of G-cysts $(40.5 \%)$ at 0.73 mbsf is illustrated clearly, as is the maximum development $(96.0 \%$ and $97.0 \%$ ) of P-cysts at 0.25 mbsf and 39.01 mbsf. The sample at this latter depth also contains minor peaks in the level of palynomorphs (with respect to amorphogen) and of microplankton (relative to foraminiferal test linings). The peak in the level of G-cysts at $0.73 \mathrm{mbsf}$ is difficult to interpret, but may reflect warmer climatic conditions (P. Mudie, pers. comm., 1989).

The overall high levels of P-cysts in the samples analyzed may well reflect the depositional environment. Upper bathyal water depths are suggested for lithologic Unit I, with volcanic ash occurring sporadically. The general lack of bioturbation indicates sedimentation under anoxic conditions, or, at best, within a low-oxygen bottom environment. These combined conditions may, directly or indirectly, have allowed peridiniacean, rather than gonyaulacacean, dinoflagellates to flourish, possibly as a result of high diatom productivity.

\section{Hole 680B Palynofacies, Palynomorph, and Microplankton Biofacies}

\section{Hole 680B Location and Samples}

Hole $680 \mathrm{~B}$ is located at $11^{\circ} 03.90^{\prime} \mathrm{S}, 78^{\circ} 04.67^{\prime} \mathrm{W}$, at a water depth of $252.5 \mathrm{~m}$. This hole reached a total depth of 195.5 mbsf. Six palynological preparations were analyzed from Hole 680B (Figs. 7 through 9). The samples at 0.29, 0.70, 4.76, 8.79, and $22.29 \mathrm{mbsf}$ are of Pleistocene age, while the sample at $89.88 \mathrm{mbsf}$ is of Pliocene age. Samples at 0.29, 0.70, 4.76, 8.79 , and 22.29 mbsf are from lithologic Unit I (thinly laminated, olive to dark gray foraminiferal diatomaceous mud and sandy silt, with minor thin ash layers); and the sample at 89.88 
Table 5. Quality control of data of studied samples from Hole 686B.

\begin{tabular}{|c|c|c|c|c|c|c|}
\hline $\begin{array}{l}\text { Core, sample, } \\
\text { interval }(\mathrm{cm})\end{array}$ & & PER & SKO & SPI & ACR & $\mathrm{n}$ \\
\hline \multirow[t]{6}{*}{$112-686 \mathrm{~B}-1 \mathrm{H}-1,17-39$} & Unoxidized & 78.5 & 3.0 & 17.5 & 1.0 & 300 \\
\hline & Oxidized & 81.5 & 0.0 & 18.0 & 0.5 & 300 \\
\hline & Difference: & +3.0 & -3.0 & +0.5 & -0.5 & \\
\hline & Unoxidized & 62.5 & 9.0 & 26.0 & 2.5 & 300 \\
\hline & Oxidized & 55.0 & 6.0 & 39.0 & 0.0 & 200 \\
\hline & Difference: & -7.5 & -3.0 & +13.0 & -2.5 & \\
\hline \multirow[t]{3}{*}{$1 \mathrm{H}-3,79-89$} & Unoxidized & 97.5 & 2.0 & 0.5 & 0.0 & 300 \\
\hline & Oxidized & 94.0 & 0.0 & 0.5 & 5.5 & 300 \\
\hline & Difference: & -3.5 & -2.0 & $+1-0.0$ & +5.5 & \\
\hline \multirow[t]{3}{*}{$1 \mathrm{H}-5,80-90$} & Unoxidized & 79.0 & 1.5 & 18.5 & 1.0 & 300 \\
\hline & Oxidized & 74.0 & 0.5 & 25.5 & 0.0 & 300 \\
\hline & Difference: & $\overline{-5.0}$ & $\overline{-1.0}$ & +7.0 & -1.0 & \\
\hline \multirow[t]{3}{*}{$3 \mathrm{H}-2,33-45$} & Unoxidized & 85.0 & 3.5 & 10.5 & 1.0 & 300 \\
\hline & Oxidized & 86.0 & 0.5 & 11.5 & 2.0 & 300 \\
\hline & Difference: & $\overline{+1.0}$ & $\overline{-3.0}$ & +1.0 & $\overline{+1.0}$ & \\
\hline \multirow[t]{2}{*}{$9 X-5,30-44$} & Unoxidized & 55.5 & 2.5 & 42.0 & 0.0 & 300 \\
\hline & Oxidized & 57.5 & 0.5 & 41.5 & 0.5 & 300 \\
\hline \multirow{5}{*}{$15 X-5,32-42$} & Difference: & +2.0 & -2.0 & -0.5 & +0.5 & \\
\hline & Unoxidized & 90.0 & 6.0 & 3.5 & 0.5 & 300 \\
\hline & Oxidized & 85.5 & 3.0 & 11.5 & 0.0 & 300 \\
\hline & Difference: & -4.5 & -3.0 & +8.0 & -0.5 & \\
\hline & Mean difference: & -2.0 & -2.5 & +4.0 & +0.5 & \\
\hline
\end{tabular}

PER = peridiniacean dinoflagellate cysts $(\mathrm{P}$-cysts $) ; \mathrm{SKO}=$ skolochorate dinoflagellate cysts (G-cysts); SPI = spiniferate dinoflagellate cysts (G-cysts); $A C R=$ acritarchs; and $\mathrm{n}=$ population of count.

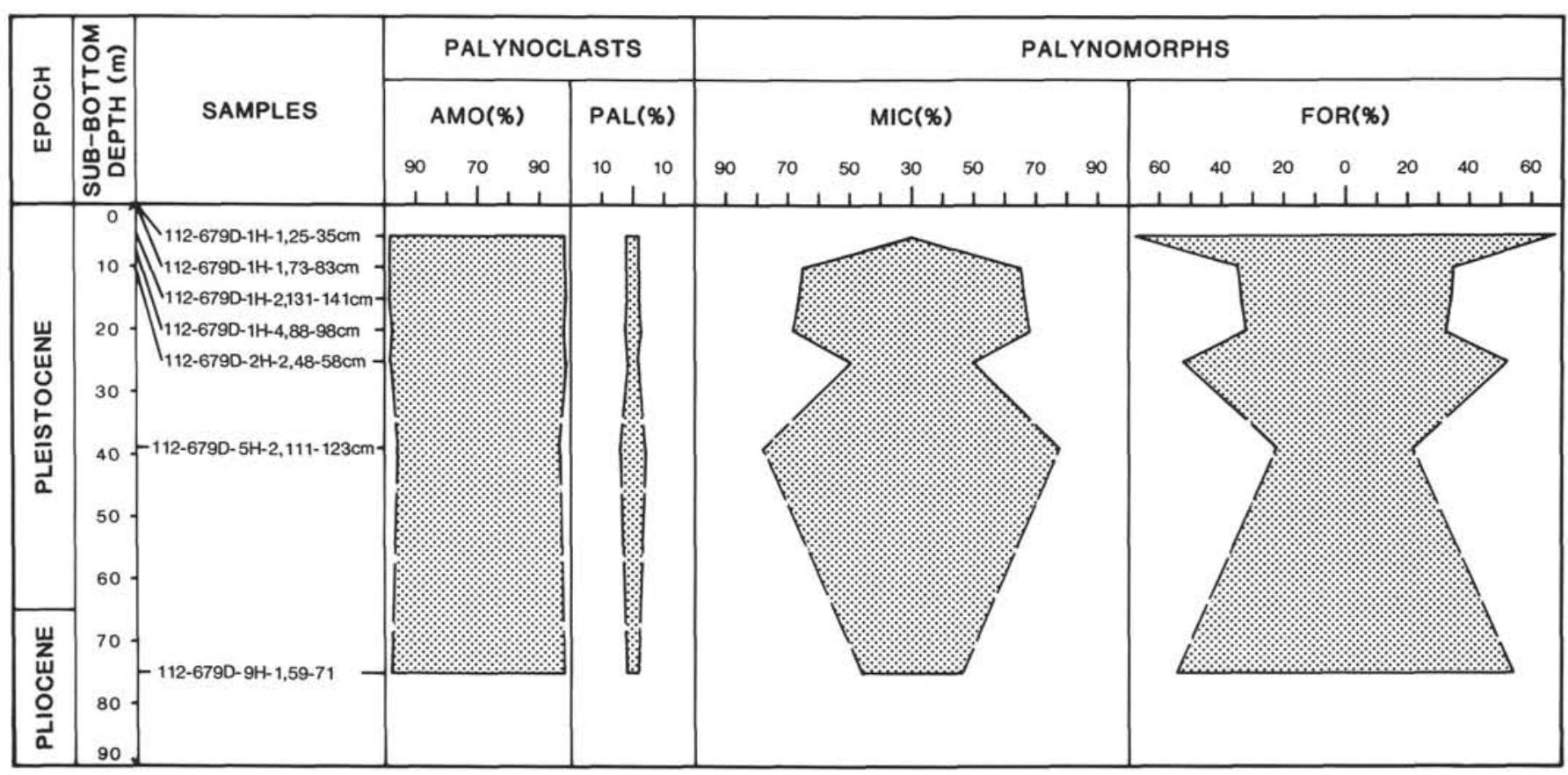

Figure 4. Palynofacies and palynomorph biofacies analysis of Hole 679D. AMO = amorphogen; PAL $=$ palynomorphs; MIC $=$ microplankton; $\mathrm{FOR}=$ foraminiferal test linings.

mbsf is from lithologic Unit IIIC (olive gray to dark olive gray feldspathic, finely laminated, diatom-bearing mud).

\section{Hole 680B Palynofacies}

In common with other sites in this study, the level of amorphogen in the palynological preparations displays an overwhelming dominance (Fig. 7), accounting, on average, for $95.0 \%$ of the assemblages. The only sample that deviates markedly from this is the one at $89.88 \mathrm{mbsf}$, which lies toward the base of lithologic Unit IIIC. At this depth, the level of amorphogen is only $79.0 \%$ with respect to the abundance of palynomorphs. This trend is illustrated most clearly in Figure 7.

Bearing in mind the large sample gap, no clear explanation exists for these observations and certainly none from this palynological evidence alone. There may be a relationship with the high terrigenous influx to the sequence below the continuous reflector penetrated at $56.6 \mathrm{mbsf}$ (see Site Chapter 680 , Suess, von Huene, et al., 1988). 


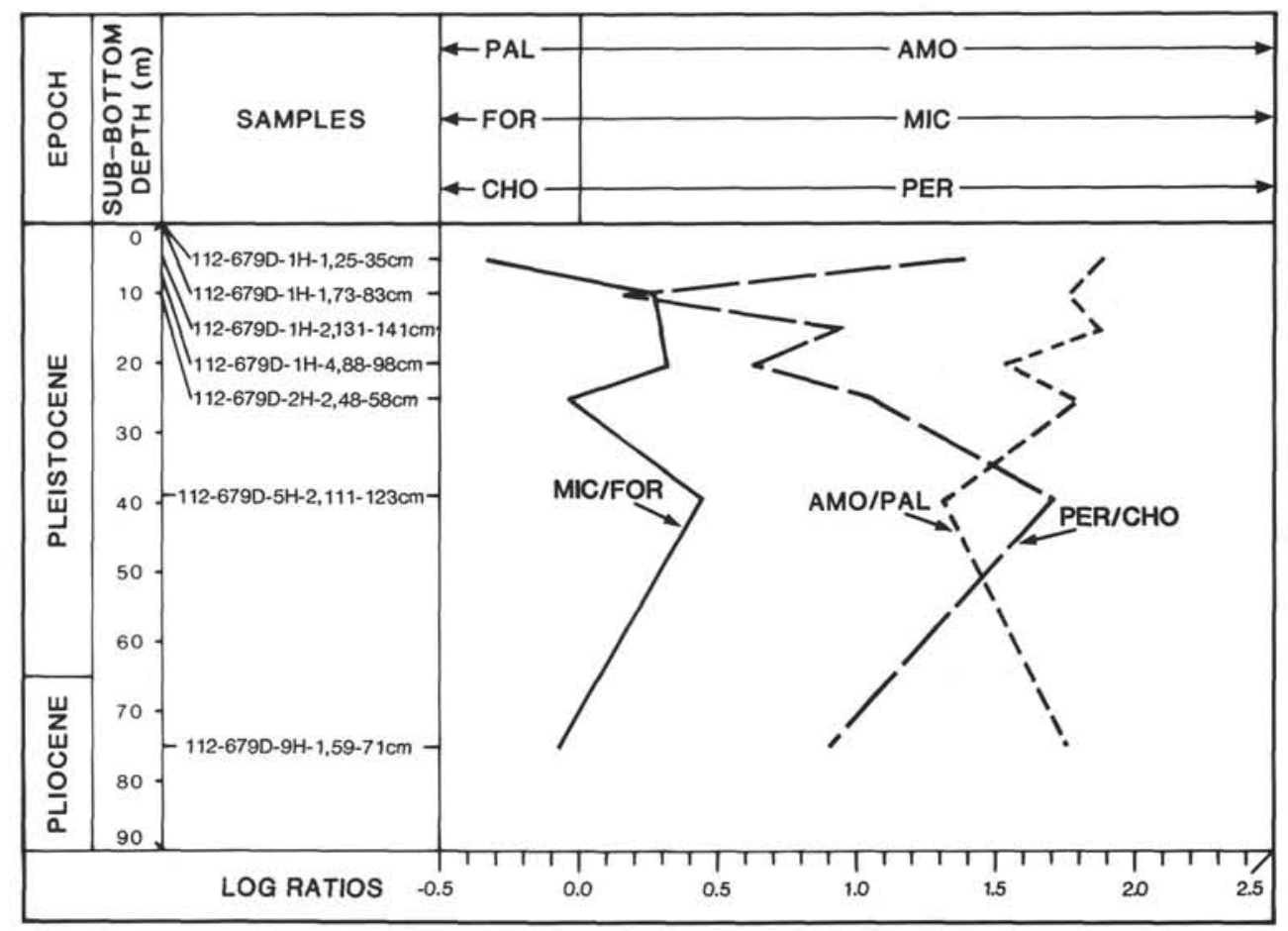

Figure 5. Palynoclast, palynomorph, and microplankton log ratios of Hole 679D. PAL $=$ palynomorphs; $\mathrm{AMO}=$ amorphogen; $\mathrm{FOR}=$ foraminiferal test linings; $\mathrm{MIC}=$ microplankton; $\mathrm{CHO}=$ chorate dinoflagellate cysts (G-cysts); PER = peridiniacean dinoflagellate cysts (P-cysts); $\mathrm{AMO} / \mathrm{PAL}=$ amorphogen/palynomorphs log ratio; $\mathrm{MIC} / \mathrm{FOR}=$ microplankton/foraminiferal test linings log ratio; $\mathrm{PER} / \mathrm{CHO}=$ peridiniacean/chorate dinoflagellate cysts $(=\mathrm{P}$-cysts/G-cysts $) \log$ ratio.

\section{Hole 680B Palynomorph Biofacies}

On average, microplankton account for $86.5 \%$ of the palynomorph assemblages (with foraminiferal test linings having a mean abundance of $13.5 \%$ ). The assemblages recognized in the samples analyzed are divisible into two distinct groups, as is clear in Figure 7. The shallowest three samples contain foraminiferal test linings at levels averaging $23.0 \%$, while the three deepest samples have abundances averaging only $4.0 \%$. This peak in the occurrence of foraminiferal test linings with respect to microplankton in the shallowest samples is a feature that was recognized at other sites, notably Holes 681B, 686B, and 687B.

The shift in the upper $5 \mathrm{~m}$ toward foraminiferal test linings, at the expense of microplankton, to some extent parallels trends in the PER/CHO (peridiniacean/chorate dinoflagellate cysts $=$ P-cysts/G-cysts) log ratio and the AMO/PAL (amorphogen/palynomorphs) log ratio (Fig. 8). Low water temperatures, deduced from organic geochemical measurements at Site 686 (Farrimond et al., this volume), may provide an explanation. This factor is discussed for Site 686 (Lewis et al., this volume) and briefly in our "Discussion" section below.

Very rare miospore specimens were recovered from the deepest sample at $89.88 \mathrm{mbsf}$. This probably reflects the greater sedimentation of terrigenous material in the succession below the continuous reflector at $56.6 \mathrm{mbsf}$.

\section{Hole 680B Microplankton Biofacies}

The stratigraphic distribution of the dinoflagellate cyst species appearing in the samples from Hole $680 \mathrm{~B}$ is summarized in Table 7. The microplankton assemblages in the upper five samples are dominated by peridiniacean dinoflagellate cysts (P-cysts), with an average abundance of $81.5 \%$. This is in marked contrast to the sample at $89.88 \mathrm{mbsf}$, which has a level of P-cysts of only $48.5 \%$. This difference is illustrated in
Figure 9. A minor peak in the abundance of gonyaulacacean dinoflagellate cysts (G-cysts) occurs in the sample at 4.76 mbsf, where spiniferate dinoflagellate cysts attain an abundance of $28.5 \%$.

Among the P-cysts appearing in the assemblages, Brigantedinium spp. are particularly common. Of the G-cysts, Spiniferites ramosus is well represented throughout, often in association with Operculodinium centrocarpum and, more rarely, with $S$. mirabilis, S. pachyderma, and Nematosphaeropsis labyrinthea.

The trend in the PER/CHO (=P-cysts/G-cysts) log ratio is shown in Figure 8 and demonstrates that the deepest sample not only has higher levels of G-cysts than the shallower samples, but also has higher levels of palynomorphs with respect to amorphogen. Thus, a broad relationship is apparent in Hole 680B between the levels of P-cysts and those of amorphogen. Low abundances of P-cysts appear to be associated with low abundances of amorphogen (or put another way, high abundances of G-cysts are associated with high abundances of palynomorphs). A certain degree of parallelism is also suggested by the MIC/FOR (microplankton/foraminiferal test linings) log ratio, inasmuch as foraminiferal test linings reach a peak in abundance in the upper $5 \mathrm{~m}$, i.e., where P-cysts are particularly dominant.

\section{Hole 681B Palynofacies, Palynomorph, and Microplankton Biofacies}

\section{Hole $681 B$ Location and Samples}

Hole $681 \mathrm{~B}$ is located at $10^{\circ} 58.60^{\prime} \mathrm{S}, 77^{\circ} 57.46^{\prime} \mathrm{W}$, at a water depth of $150.5 \mathrm{~m}$. This hole reached a total depth of 143.5 mbsf. Seven palynological preparations were analyzed from Hole 681B (Figs. 10 through 12). All samples are of Pleistocene age. Samples at $0.36,0.81,8.23$, and 12.24 mbsf are from lithologic Unit I (laminated diatomaceous mud, with 
Table 6. Dinoflagellate cyst species distribution list for Hole 679D.

\begin{tabular}{|c|c|c|c|c|c|c|c|}
\hline Samples & 1 & 2 & 3 & 4 & 5 & 6 & 7 \\
\hline \multicolumn{8}{|l|}{ G-cysts: } \\
\hline $\begin{array}{l}\text { Impagidinium aculeatum (Wall, } \\
\text { 1967) Harland, } 1983\end{array}$ & $\mathbf{R}$ & - & - & - & R & - & - \\
\hline $\begin{array}{l}\text { Lingulodinium machaerophorum } \\
\text { (Deflandre and Cookson, 1955) } \\
\text { Wall, } 1967\end{array}$ & - & - & - & - & - & - & $\mathbf{R}$ \\
\hline $\begin{array}{l}\text { Melitasphaeridium choanophorum } \\
\text { (Deflandre and Cookson, 1955) } \\
\text { Harland and Hill, } 1979\end{array}$ & - & - & - & - & - & - & $\mathrm{R}$ \\
\hline $\begin{array}{l}\text { Nematosphaeropsis labyrinthea } \\
\text { (Ostenfeld, 1900) Reid, } 1974\end{array}$ & R & $\mathrm{F}$ & $\mathbf{R}$ & - & $\mathbf{R}$ & - & $\mathbf{R}$ \\
\hline $\begin{array}{l}\text { Operculodinium centrocarpum } \\
\text { (Deflandre and Cookson, 1955) } \\
\text { Wall, } 1967\end{array}$ & R & - & - & F & - & - & $\mathbf{R}$ \\
\hline $\begin{array}{l}\text { Spiniferites hyperacanthus } \\
\text { (Deflandre and Cookson, 1955) } \\
\text { Cookson and Eisenack, 1974 }\end{array}$ & - & $R$ & $\mathbf{R}$ & $R$ & R & $\mathrm{R}$ & - \\
\hline $\begin{array}{l}\text { Spiniferites membranaceus } \\
\text { (Rossignol, 1964) Sarjeant, } 1970\end{array}$ & - & $\mathbf{R}$ & - & - & R & $\mathbf{R}$ & - \\
\hline $\begin{array}{l}\text { Spiniferites mirabilis (Rossignol, } \\
\text { 1963) Sarjeant, } 1970\end{array}$ & $\mathbf{R}$ & $\mathbf{R}$ & - & $\mathrm{R}$ & F & - & $\mathrm{R}$ \\
\hline $\begin{array}{l}\text { Spiniferites pachyderma (Rossignol, } \\
\text { 1964) Reid, } 1974\end{array}$ & - & - & $\mathrm{R}$ & $\mathrm{F}$ & - & - & - \\
\hline $\begin{array}{l}\text { Spiniferites ramosus (Ehrenberg, } \\
\text { 1838) Loeblich and Loeblich, } 1966\end{array}$ & $\mathbf{R}$ & A & $\mathrm{F}$ & $\mathrm{F}$ & A & A & $\mathrm{C}$ \\
\hline Spiniferites spp. undiff. & - & $\mathrm{F}$ & $\mathbf{R}$ & $\mathbf{R}$ & $\mathrm{F}$ & R & $\mathbf{R}$ \\
\hline \multicolumn{8}{|l|}{ P-cysts: } \\
\hline & A & A & A & A & A & A & A \\
\hline Dubrid & R & R & $\mathbf{R}$ & R & - & - & 二 \\
\hline & - & - & - & $\mathrm{F}$ & - & $\mathbf{R}$ & $\overline{-}$ \\
\hline $\begin{array}{r}\text { Protope } \\
\text { and B }\end{array}$ & F & R & - & - & - & R & $\mathbf{R}$ \\
\hline $\begin{array}{l}\text { Quinquecuspis concretum (Reid, } \\
\text { 1977) Harland, } 1977\end{array}$ & $\mathbf{R}$ & R & R & $\mathbf{R}$ & $\mathbf{R}$ & $\mathbf{R}$ & $\mathbf{R}$ \\
\hline Scrippsiella sp & $\mathbf{R}$ & - & $\mathbf{R}$ & $\mathrm{R}$ & - & $\mathrm{C}$ & - \\
\hline $\begin{array}{l}\text { Selenopemphix nephroides Benedek, } \\
1972 \text { emend. Benedek and } \\
\text { Sarjeant, } 1981\end{array}$ & - & 一 & - & - & - & - & R \\
\hline $\begin{array}{l}\text { Selenopemphix quanta (Bradford, } \\
\text { 1975) Matsuoka, } 1986\end{array}$ & - & $\mathbf{R}$ & $\mathrm{F}$ & $\mathrm{R}$ & $\mathrm{F}$ & A & $\mathrm{F}$ \\
\hline $\begin{array}{l}\text { Trinovantedinium capitatum Reid, } \\
1977\end{array}$ & - & - & $\mathrm{R}$ & - & $\mathrm{F}$ & $\mathrm{R}$ & $\mathrm{F}$ \\
\hline Votadinium calvum Reid, 1977 & $\mathrm{R}$ & $\mathbf{R}$ & $\mathbf{R}$ & - & & - & $\mathbf{R}$ \\
\hline Votadinium spinosum Reid, 1977 & R & - & - & - & & - & \\
\hline \multicolumn{8}{|l|}{ Other cysts: } \\
\hline Polukrikes est & $\bar{F}$ & $\overline{\mathrm{R}}$ & $\bar{R}$ & $\overline{\mathrm{F}}$ & $\overline{\mathrm{R}}$ & $\bar{R}$ & $\begin{array}{l}R \\
R\end{array}$ \\
\hline Unidentified forms & $\mathrm{R}$ & $\mathrm{R}$ & $\mathrm{R}$ & - & $\mathrm{F}$ & $\mathrm{R}$ & F \\
\hline
\end{tabular}

$1=112-679 \mathrm{D}-1 \mathrm{H}-1,25-35 \mathrm{~cm}(0.25 \mathrm{mbsf}) ; 2=112-679 \mathrm{D}-1 \mathrm{H}-1,73-83 \mathrm{~cm}(0.73$ mbsf); 3 = 112-679D-1H-2, 131-141 cm (2.80 mbsf); 4 = 112-679D-1H-4, 88-98 $\mathrm{cm}(5.38 \mathrm{mbsf}) ; 5=112-679 \mathrm{D}-2 \mathrm{H}-2,48-58 \mathrm{~cm}(9.88 \mathrm{mbsf}) ; 6=112-679 \mathrm{D}-5 \mathrm{H}-2$, $111-123 \mathrm{~cm}(39.01 \mathrm{mbsf}) ; 7=112-679 \mathrm{D}-9 \mathrm{H}-1,59-71 \mathrm{~cm}(74.99 \mathrm{mbsf}) ; \mathrm{R}=$ rare $(<3 \%) ; \mathrm{F}=$ few $(3 \%-15 \%) ; \mathrm{C}=$ common $(15 \%-30 \%) ; \mathrm{A}=$ abundant $(>30 \%)$.

sandy/silty beds containing clasts of volcanic origin); samples at 40.97 and 84.60 mbsf are from lithologic Unit II (interbedded terrigenous mud and diatomaceous mud, with common sand and silt beds); and the sample at $112.50 \mathrm{mbsf}$ is from lithologic Unit III (laminated diatomaceous mud).

\section{Hole 681B Palynofacies}

Like samples from the other holes studied, those samples analyzed from Hole 681B are dominated by amorphogen relative to palynomorphs, as shown in Figure 10. Amorphogen, on average, accounts for $97.0 \%$ of the assemblage. The sample at 12.24 mbsf is different from the other samples in that it has a high representation of palynomorphs $(10.5 \%$, as opposed to the average of $3.0 \%$ ). The shift toward palynomorphs at this depth is also illustrated in Figure 11 by the AMO/PAL (amorphogen/palynomorphs) log ratio. This sample was taken from a bioturbated unit between 12 and 15 mbsf.

\section{Hole 681B Palynomorph Biofacies}

Microplankton are particularly well represented in the sample suite from Hole $681 \mathrm{~B}$, accounting for an average of $80.0 \%$ of the palynomorph assemblage. Microplankton attain a peak of $89.5 \%$ at 8.23 mbsf before declining in the upper two samples $(74.0 \%$ and $73.0 \%$ ). At the latter depths, foraminiferal test linings are relatively abundant, with an average abundance of $26.5 \%$ (Fig. 10). The MIC/FOR (microplankton/ foraminiferal test linings) log ratio illustrates the peak in abundance of foraminiferal test linings in the shallowest samples (Fig. 11). This trend was observed in other holes.

\section{Hole 681B Microplankton Biofacies}

The stratigraphic distribution of the dinoflagellate cyst species appearing in samples from Hole $681 \mathrm{~B}$ is summarized in Table 8. From Figure 12, one can see that spheroidal brown cysts, referable to the genus Brigantedinium, dominate the peridiniacean (P-cyst) part of the microplankton assemblages. On average, these cysts account for $93.0 \%$ of the assemblage, with a maximum value of $97.0 \%$ in the two shallowest samples (where foraminiferal test linings are also particularly common).

The gonyaulacacean component (G-cysts) of the microplankton assemblages is poorly represented. Skolochorate cysts appear at average levels of $1.5 \%$, while spiniferate species occur at slightly higher levels $(4.0 \%)$. Of these species, Spiniferites ramosus, and to a lesser degree, S. mirabilis and Operculodinium centrocarpum are the most characteristic.

One sample deviates from this pattern: at $12.24 \mathrm{mbsf}$ where spiniferate cysts increase to a value of $14.5 \%$ and P-cysts decrease to $78.5 \%$. This trend, well illustrated in Figure 11, is parallel to a shift toward palynomorphs in the AMO/PAL log ratio. An explanation may be that this sample is from a bioturbated unit recovered between 12 and 125 mbsf in Hole 681B and may reflect warmer climatic conditions (P. Mudie, pers. comm., 1989).

\section{Hole 684B Palynofacies, Palynomorph and Microplankton Biofacies}

\section{Hole 684B Locations and Samples}

Hole $684 \mathrm{~B}$ is located at $8^{\circ} 59.49^{\prime} \mathrm{S}$ and $79^{\circ} 54.35^{\prime} \mathrm{W}$, at a water depth of $426.5 \mathrm{~m}$. This hole reached a total depth of 55 mbsf. Six palynological preparations were analyzed from Hole 684B (Figs. 13 through 15). Samples at $0.13,0.63,3.81$, and 6.82 mbsf are of Pleistocene age, while samples at 27.67 and $35.61 \mathrm{mbsf}$ are of Pliocene age. Samples at $0.36,0.13,0.63$, 3.81 , and $6.82 \mathrm{mbsf}$ are from lithologic Unit IA (laminated diatomaceous mud); and samples at 27.67 and $35.61 \mathrm{mbsf}$ are from lithologic Unit III (bioturbated, calcareous diatomaceous mud).

\section{Hole 684B Palynofacies}

As can be seen in Figure 13, the palynoclast assemblages from Hole 684B show little variation between the samples analyzed. Levels of amorphogen occur in the region of $98.0 \%$, which is marginally higher than the average for all studied samples $(96.5 \%)$. We do not think this is significant.

\section{Hole 684B Palynomorph Biofacies}

Microplankton exhibit a clear downhole increase in abundance relative to the levels of foraminiferal test linings (Fig. 13). The latter are well represented in the five shallowest samples (averaging $37.0 \%$ ), but are depleted drastically in the deepest sample at 35.61 mbsf. Apparently, the Pleistocene samples from the predominantly laminated lithologic Unit IA contain more foraminiferal test linings than those from the 


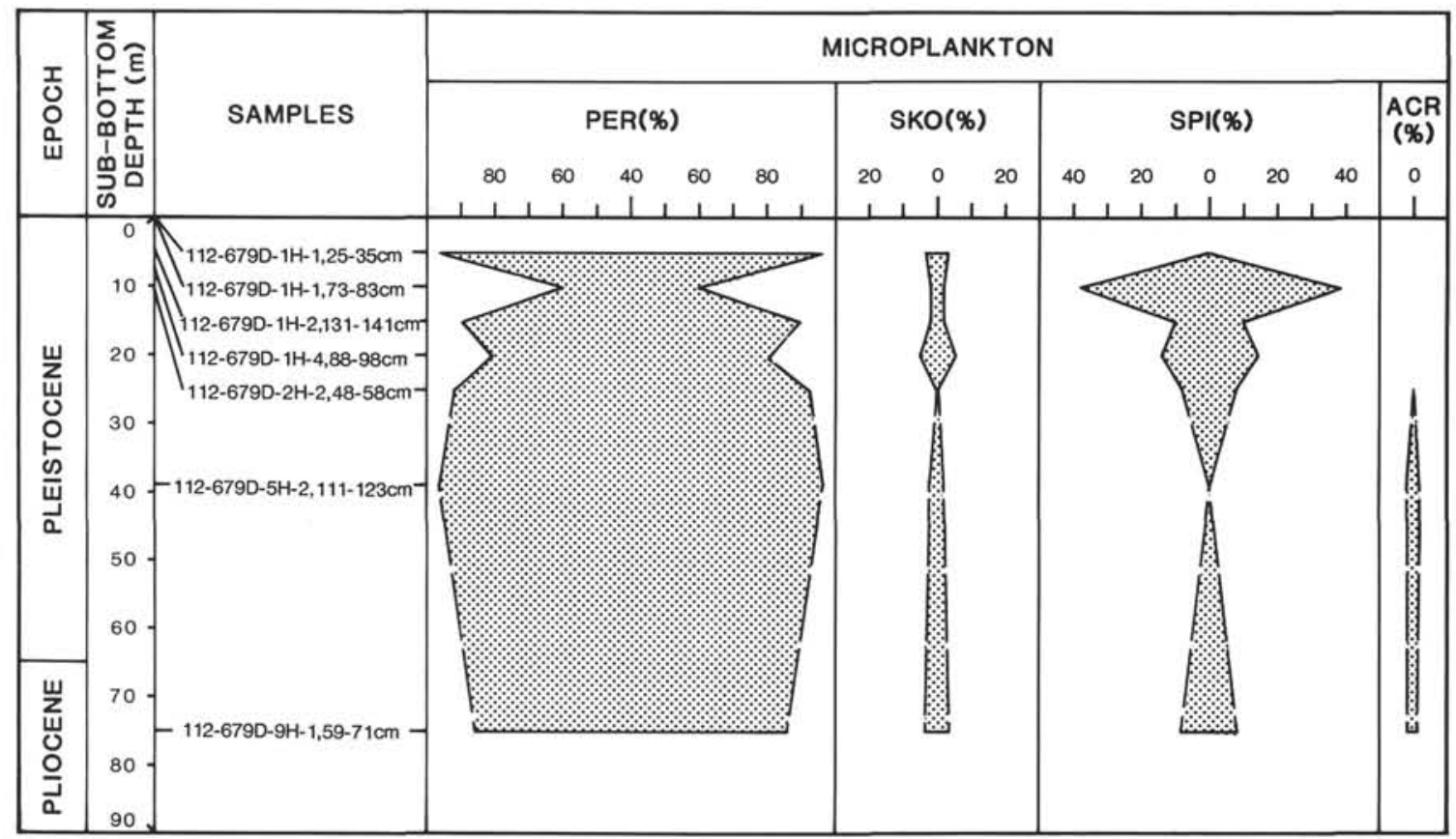

Figure 6. Microplankton biofacies analysis of Hole 679D. PER = peridiniacean dinoflagellate cysts $(\mathrm{P}-\mathrm{cysts}) ; \mathrm{SKO}=$ skolochorate dinoflagellate cysts (G-cysts); SPI = spiniferate dinoflagellate cysts (G-cysts); ACR = acritarchs.

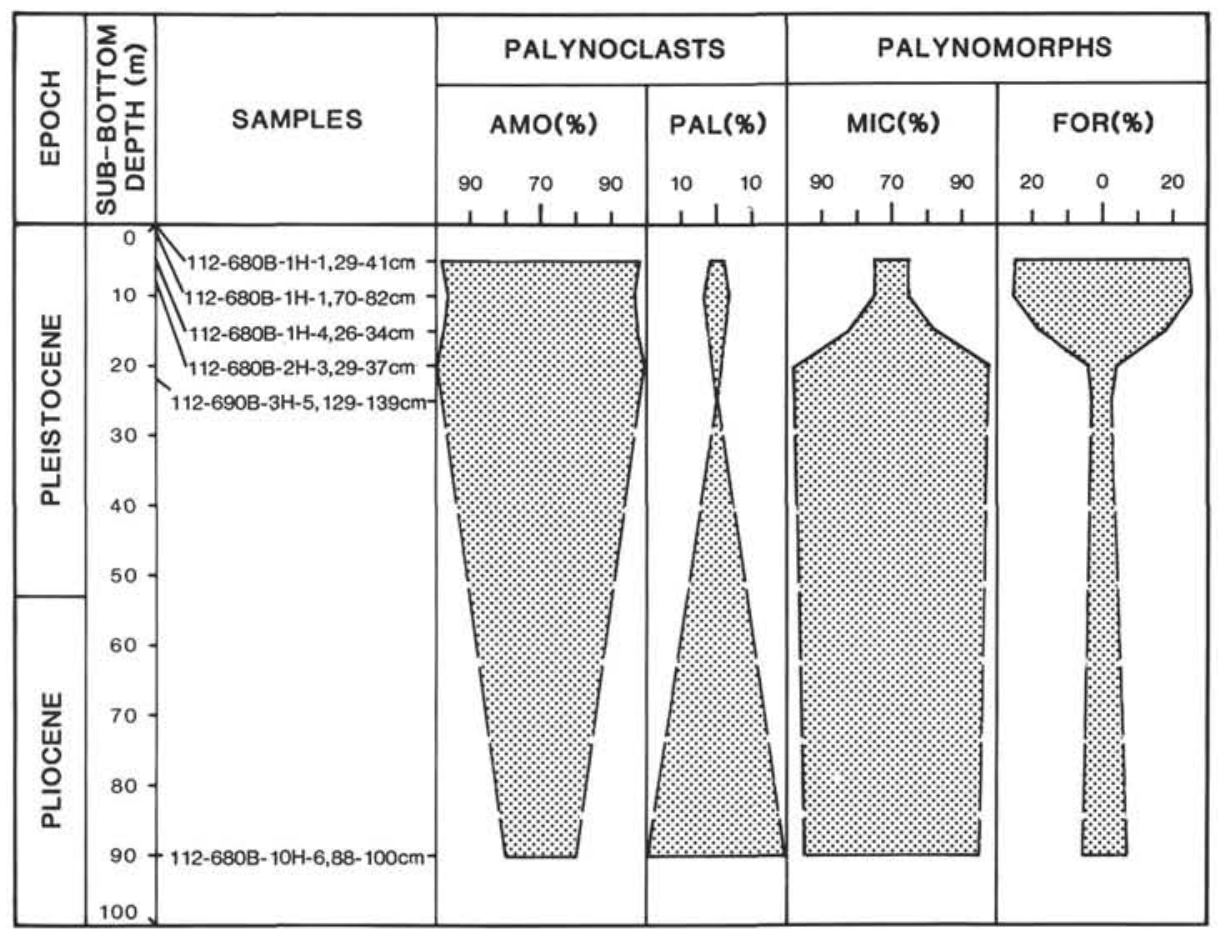

Figure 7. Palynofacies and palynomorph biofacies analysis of Hole $680 \mathrm{~B}$. AMO $=$ amorphogen; $\mathrm{PAL}=$ palynomorphs $; \mathrm{MIC}=$ microplankton $; \mathrm{FOR}=$ foraminiferal test linings. 


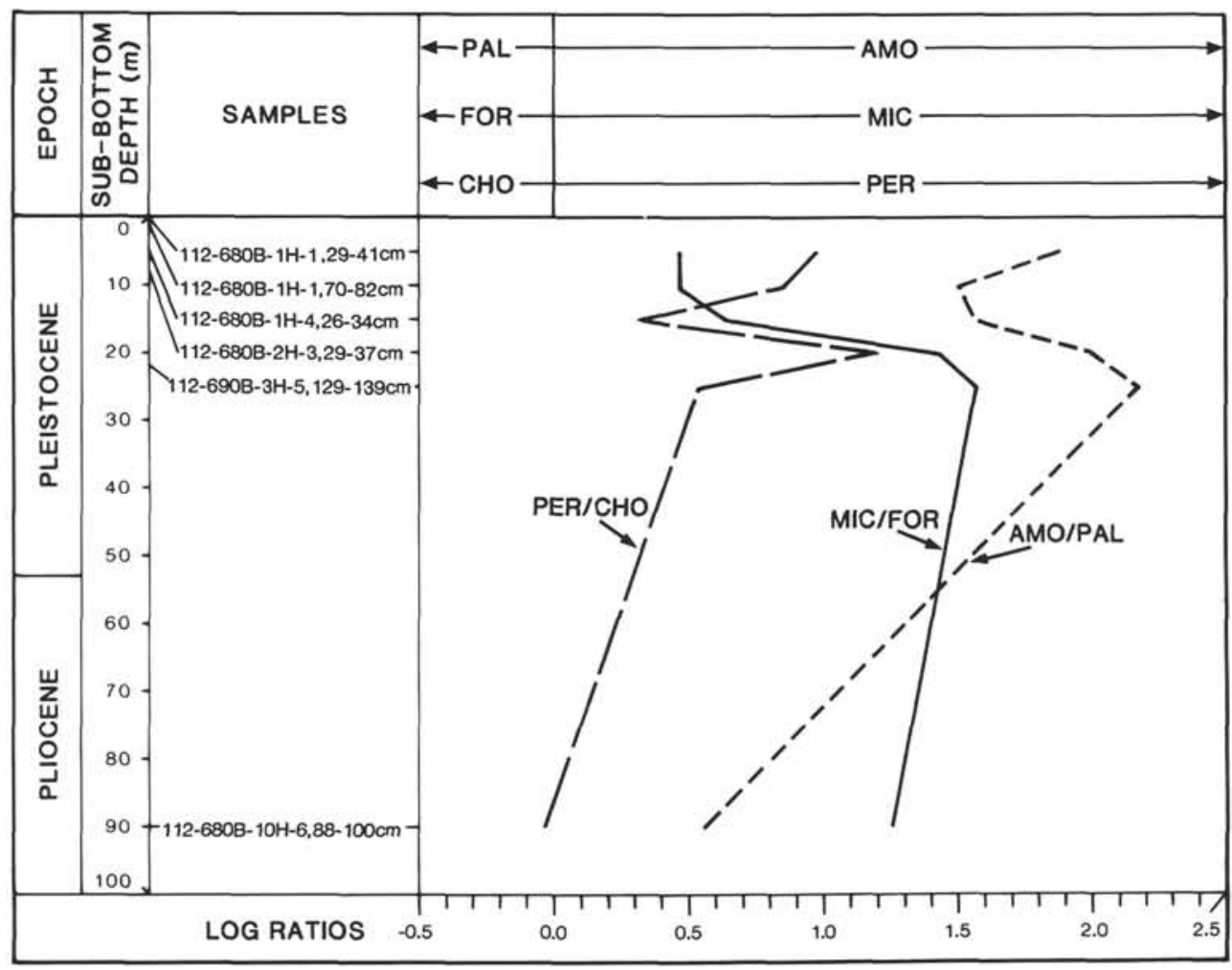

Figure 8. Palynoclast, palynomorph, and microplankton log ratios of Hole $680 \mathrm{~B}$. PAL $=$ palynomorphs; $\mathrm{AMO}=$ amorphogen; FOR $=$ foraminiferal test linings; $\mathrm{MIC}=$ microplankton; $\mathrm{CHO}=$ chorate dinoflagellate cysts (G-cysts); PER = peridiniacean dinoflagellate cysts $(\mathrm{P}$-cysts); $\mathrm{AMO} / \mathrm{PAL}=$ amorphogen/palynomorphs log ratio; $\mathrm{MIC} / \mathrm{FOR}=$ microplankton/foraminiferal test linings log ratio; $\mathrm{PER} / \mathrm{CHO}=$ peridiniacean/chorate dinoflagellate cysts $(=\mathrm{P}$-cysts/G-cysts $)$ log ratio.

bioturbated Pliocene Unit III. This trend is also shown in Figure 14 by the MIC/FOR (microplankton/foraminiferal test linings) $\log$ ratio.

Of note is the recovery, in trace levels, of the freshwater alga Pediastrum in the samples at 0.63 and 3.81 mbsf. Pediastrum commonly marks glacial meltwater events in marine sediments (P. Mudie, pers. comm., 1989). Contamination is a possible explanation for its recovery, unless runoff from the mainland may be considered feasible in this setting.

\section{Hole 684B Microplankton Biofacies}

The stratigraphic distribution of the dinoflagellate cyst species appearing in the samples from Hole 684B is summarized in Table 9. A clear dichotomy exists in the sample suite from Hole $684 \mathrm{~B}$ in terms of the microplankton assemblages observed (Fig. 15). The Pleistocene samples from lithologic Unit IA are dominated by peridiniacean dinoflagellate cysts (P-cysts), while samples from the Pliocene lithologic Unit III are dominated, albeit to a lesser degree, by spiniferate dinoflagellate cysts (G-cysts). This may be an expression of the influence of upwelling on the assemblage composition; the Pliocene lithologic Unit III being of a bioturbated nature and thus deposited under oxygenated conditions. This difference is also shown in Figure 14 by the PER/CHO (peridiniacean/chorate dinoflagettalte cysts $=$ P-cysts $/$ G-cysts) $\log$ ratio.

Note that the shift in favor of G-cysts is not paralleled by an increase in palynomorphs with respect to amorphogen, as might be expected. However, the reduction in levels of foraminiferal test linings occurs in the same samples as the reduction of P-cysts.
As in other holes examined for this study, the P-cyst component of the microplankton assemblages is dominated by Brigantedinium spp. and, to a lesser extent, by Selenopemphix spp. The G-cyst assemblages are characterized particularly by Spiniferites ramosus and Operculodinium centrocarpum.

\section{Hole 686B Palynofacies, Palynomorph, and Microplankton Biofacies}

\section{Hole 686B Location and Samples}

Hole $686 \mathrm{~B}$ is located at $13^{\circ} 28.81^{\prime} \mathrm{S}$ and $76^{\circ} 53.49^{\prime} \mathrm{W}$, at a water depth of $446.8 \mathrm{~m}$. This hole reached a total depth of 303.00 mbsf. Seven palynological preparations were analyzed from Hole 686B (Figs. 16 through 18). All samples are of Pleistocene age. Samples at $0.30,0.87,3.79,6.80$, and 19.83 mbsf are from lithologic Unit I (laminated diatomaceous mud with thin sand and silt layers); the sample at $80.08 \mathrm{mbsf}$ is from lithologic Unit II (burrowed diatomaceous mud with beds of sand and silt); and that at 138.32 mbsf is from lithologic Unit III (laminated diatomaceous mud).

\section{Hole 686B Palynofacies Assemblages}

Levels of amorphogen in the samples from Hole 686B (see Fig. 16) are at a mean level of $95.0 \%$, which is near the grand mean for all samples analyzed here. One sample, at $0.87 \mathrm{mbsf}$, deviates a small degree in that the abundance of palynomorphs within the palynoclast assemblage is high at $15.0 \%$ (amorphogen at $85.0 \%$ ). This phenomenon in the AMO/PAL (amorphogen/palynomorphs) log ratio is illustrated in Figure 17. In the same sample, foraminiferal test linings are abundant, as 
Table 7. Dinoflagellate cyst species distribution list for Hole $680 \mathrm{~B}$.

\begin{tabular}{|c|c|c|c|c|c|c|}
\hline Samples & 1 & 2 & 3 & 4 & 5 & 6 \\
\hline \multicolumn{7}{|l|}{ G-cysts: } \\
\hline $\begin{array}{l}\text { Impagidinium aculeatum (Wall, } \\
\text { 1967) Harland, } 1983\end{array}$ & - & - & $\mathbf{R}$ & - & - & - \\
\hline $\begin{array}{l}\text { Lingulodinium machaerophorum } \\
\text { (Deflandre and Cookson, 1955) } \\
\text { Wall, } 1967\end{array}$ & - & - & - & $\mathrm{R}$ & - & - \\
\hline $\begin{array}{l}\text { Nematosphaeropsis labyrinthea } \\
\text { (Ostenfeld, 1900) Reid, } 1974\end{array}$ & $\mathrm{~F}$ & $\mathrm{~F}$ & $\mathbf{R}$ & - & - & - \\
\hline $\begin{array}{l}\text { Operculodinium centrocarpum } \\
\text { (Deflandre and Cookson, 1955) } \\
\text { Wall, } 1967\end{array}$ & $\mathbf{R}$ & $\mathrm{R}$ & $\mathbf{R}$ & $\mathbf{R}$ & C & C \\
\hline $\begin{array}{l}\text { Spiniferites bentorii (Rossignol, 1964) } \\
\text { Wall and Dale, } 1970\end{array}$ & - & - & - & - & $\mathbf{R}$ & - \\
\hline Spiniferites delicatus Reid, 1974 & $\mathbf{R}$ & $\mathbf{R}$ & $\mathrm{R}$ & $\mathrm{F}$ & - & - \\
\hline $\begin{array}{l}\text { Spiniferites hyperacanthus } \\
\text { (Deflandre and Cookson, 1955) } \\
\text { Cookson and Eisenack, 1974 }\end{array}$ & $\mathbf{R}$ & $\mathbf{R}$ & $\mathrm{R}$ & $\mathrm{R}$ & $\mathbf{R}$ & $\mathbf{R}$ \\
\hline $\begin{array}{l}\text { Spiniferites membranaceus } \\
\quad \text { (Rossignol, 1964) Sarjeant, } 1970\end{array}$ & - & - & $\mathrm{R}$ & - & - & - \\
\hline $\begin{array}{l}\text { Spiniferites mirabilis (Rossignol, } \\
\text { 1963) Sarjeant, } 1970\end{array}$ & $\mathrm{R}$ & $\mathbf{R}$ & $\mathbf{R}$ & C & $\mathbf{R}$ & A \\
\hline $\begin{array}{l}\text { Spiniferites pachyderma (Rossignol, } \\
\text { 1964) Reid, } 1974\end{array}$ & - & - & $\mathrm{F}$ & C & A & - \\
\hline $\begin{array}{l}\text { Spiniferites ramosus (Ehrenberg, } \\
\text { 1838) Loeblich and Loeblich, } 1966\end{array}$ & $\mathrm{~F}$ & F & A & $\mathrm{C}$ & $\mathbf{R}$ & A \\
\hline Spiniferites spp. undiff. & $\mathrm{F}$ & $\mathrm{R}$ & $\mathbf{R}$ & $\mathrm{F}$ & $\mathbf{R}$ & $\mathrm{F}$ \\
\hline Tectatodinium pellitum Wall, 1967 & - & - & - & R & - & 一 \\
\hline \multicolumn{7}{|l|}{ P-cysts: } \\
\hline Brigantediniu & A & A & - & F & - & - \\
\hline Dubridinit & $\mathrm{R}$ & $\mathrm{R}$ & - & - & - & - \\
\hline Paulsen, 1905 & - & - & $\mathrm{F}$ & $\mathbf{R}$ & - & $\mathbf{R}$ \\
\hline $\begin{array}{l}\text { Protoperidinium americanum (Gran } \\
\text { and Braarud, 1935) Balech, } 1974\end{array}$ & $\mathrm{~F}$ & $\mathrm{~F}$ & $\mathbf{R}$ & $\mathbf{R}$ & - & \\
\hline $\begin{array}{l}\text { Quinquecuspis concretum (Reid, } \\
\text { 1977) Harland, } 1977\end{array}$ & $\mathrm{R}$ & $\mathrm{R}$ & $\mathbf{R}$ & $\mathbf{R}$ & - & - \\
\hline Scrippsiella spp. undiff. & - & - & - & $\mathrm{F}$ & - & - \\
\hline $\begin{array}{l}\text { Selenopemphix nephroides Benedek, } \\
1972 \text { emend. Benedek and } \\
\text { Sarjeant, } 1981\end{array}$ & $\mathrm{R}$ & R & R & $\mathrm{F}$ & - & \\
\hline $\begin{array}{l}\text { Selenopemphix quanta (Bradford, } \\
\text { 1975) Matsuoka, } 1986\end{array}$ & $\mathbf{R}$ & $\mathbf{R}$ & $\mathrm{F}$ & $\mathrm{F}$ & - & $\mathbf{R}$ \\
\hline $\begin{array}{l}\text { Trinovantedinium capitatum Reid, } \\
1977\end{array}$ & - & - & $\mathbf{R}$ & - & - & - \\
\hline Votadinium calvum Reid, 1977 & $\mathbf{R}$ & $\mathbf{R}$ & - & - & - & \\
\hline Votadinium spinosum Reid, 1977 & $\mathrm{R}$ & $\mathrm{R}$ & - & - & - & \\
\hline $\begin{array}{l}\text { Other cysts: } \\
\text { Spiny forms }\end{array}$ & $\mathrm{C}$ & $\mathrm{C}$ & - & - & - & - \\
\hline
\end{tabular}

Sample $1=112-680 \mathrm{~B}-1 \mathrm{H}-1,29-41 \mathrm{~cm}(0.29 \mathrm{mbsf}) ; 2=112-680 \mathrm{~B}-1 \mathrm{H}-1$, $70-82 \mathrm{~cm}(0.70 \mathrm{mbsf}) ; 3=112-680 \mathrm{~B}-1 \mathrm{H}-4,26-34 \mathrm{~cm}(4.76 \mathrm{mbsf}) ; 4=$ $112-680 \mathrm{~B}-2 \mathrm{H}-3,29-37 \mathrm{~cm}(8.79 \mathrm{mbsf}) ; 5=112-680 \mathrm{~B}-3 \mathrm{H}-5,129-139 \mathrm{~cm}$ (22.29 mbsf); $6=112-680 \mathrm{~B}-10 \mathrm{H}-6,88-100 \mathrm{~cm}(89.88 \mathrm{mbsf}) ; \mathrm{R}=$ rare $(<3 \%) ; \mathrm{F}=$ few $(3 \%-15 \%) ; \mathrm{C}=$ common $(15 \%-30 \%) ; \mathrm{A}=$ abundant $(>30 \%)$.

are spiniferate dinoflagellate cysts (G-cysts), discussed more completely below.

\section{Hole 686B Palynomorph Biofacies}

Two distinct palynomorph assemblages are evident in the sample suite from Hole 686B (Fig. 16). Those samples within the upper $6.8 \mathrm{mbsf}$ have a high representation of foraminiferal test linings (37.0\% mean). Samples at $19.83,80.08$, and 138.32 mbsf, however, constitute a different assemblage. At these depths, there are reduced levels of foraminiferal test linings (10.5\% mean) and an enrichment of microplankton.

The high abundance of foraminiferal test linings in the upper part of the Pleistocene succession is a phenomenon that was observed at other sites studied. The relationship between the MIC/FOR (microplankton/foraminiferal test linings) log ratio (Fig. 17) and sedimentation with respect to oxygen levels is not clear. Water temperature at the time of deposition may have been a more influential controlling factor.

\section{Hole 686B Microplankton Biofacies}

The stratigraphic distribution of the dinoflagellate cyst species appearing in the samples from Hole $686 \mathrm{~B}$ is summarized in Table 10. Within the peridiniacean (P-cysts) component of the microplankton assemblages, spheroidal brown cysts (mostly of the genus Brigantedinium) are dominant. Selenopemphix spp., although less frequent, also are characteristic. The gonyaulacacean (G-cysts) assemblages are dominated by Spiniferites ramosus, with lower levels of $S$. mirabilis, Operculodinium centrocarpum, and Nematosphaeropsis labyrinthea.

From Figure 18 one can see that samples from the predominantly laminated lithologic Unit I are dominated by P-cysts. The same is true for a sample at $138.32 \mathrm{mbsf}$ from lithologic Unit III, which is also characterized by laminated sediments. The mean level of P-cyst abundance is $78.0 \%$ for Hole $686 \mathrm{~B}$, which is slightly below the average for all samples studied here $(82.0 \%)$.

The sample at 3.79 mbsf contains a particularly high abundance of P-cysts (97.5\%). Figure 17 demonstrates that it is at this depth that a minor shift occurs in favor of microplankton in the $\mathrm{MIC} / \mathrm{FOR} \log$ ratio, as well as a slight decrease in the level of palynomorphs in the AMO/PAL log ratio. In general terms, shifts in the PER/CHO (peridiniacean/ chorate dinoflagellate cysts $=$ P-cysts/G-cysts) log ratio are paralleled by shifts in both the MIC/FOR and the AMO/PAL log ratios. Thus, an increase in P-cysts is accompanied by an increase in microplankton and amorphogen. Conversely, an increase in G-cysts is accompanied by an increase in foraminiferal test linings and palynomorphs.

The one sample that deviates from this P-cyst dominance is that from bioturbated lithologic Unit II ( $80.08 \mathrm{mbsf})$. At this depth, spiniferate cysts increase to an abundance of $42.0 \%$, decreasing the level of P-cysts to $55.5 \%$. The effect of sedimentation within an oxygenated environment may explain this trend.

\section{Hole 687B Palynofacies, Palynomorph, and Microplankton Biofacies}

\section{Hole 687B Location and Samples}

Hole $687 \mathrm{~B}$ is located at $12^{\circ} 51.78^{\prime} \mathrm{S}, 76^{\circ} 59.43^{\prime} \mathrm{W}$, at a water depth of $306.8 \mathrm{~m}$. This hole reached a total depth of 195.3 mbsf. Seven palynological preparations were analyzed from Hole 687B (Figs. 19 through 21). All samples are of Pleistocene age, except that at 160.89 mbsf, which is Pliocene in age. Samples at $0.38,0.79,3.86$, and $19.58 \mathrm{mbsf}$ are from lithologic Unit IA (laminated, diatomaceous mud); samples at 47.31 and 53.32 mbsf are from lithologic Unit IB (bioturbated, calcareous silty mud and silt); and the sample at $160.89 \mathrm{mbsf}$ is from lithologic Unit IIIB (dolomitic, calcareous diatomaceous silty mud).

\section{Hole 687B Palynofacies}

In common with other Leg 112 holes, amorphogen dominates the palynoclast assemblages emphatically, with an average value of $97.0 \%$, as represented in Figure 19. Levels of amorphogen are uniformly high, and there are apparently no significant trends in the AMO/PAL (amorphogen/palynomorphs) log ratio (Fig. 20) throughout Hole 687B. Samples at 0.79 and 53.32 mbsf have the highest amorphogen levels ( $98.5 \%$ and $99.0 \%$, respectively), but this is unlikely to have any statistical significance. 


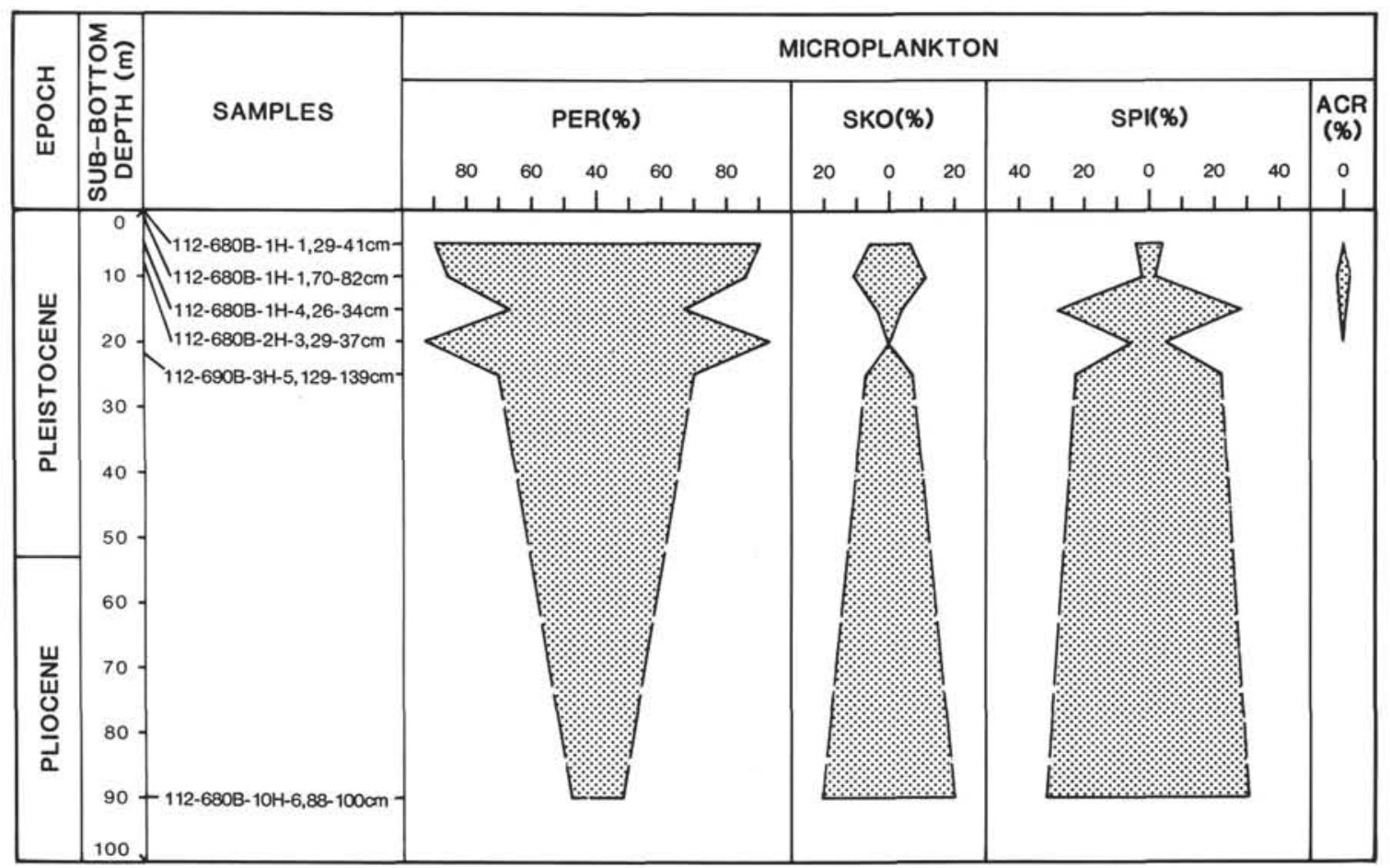

Figure 9. Microplankton biofacies analysis of Hole 680B. PER = peridiniacean dinoflagellate cysts $(\mathrm{P}-\mathrm{cysts}) ; \mathrm{SKO}=$ skolochorate dinoflagellate cysts (G-cysts); SPI = spiniferate dinoflagellate cysts (G-cysts); ACR = acritarchs.

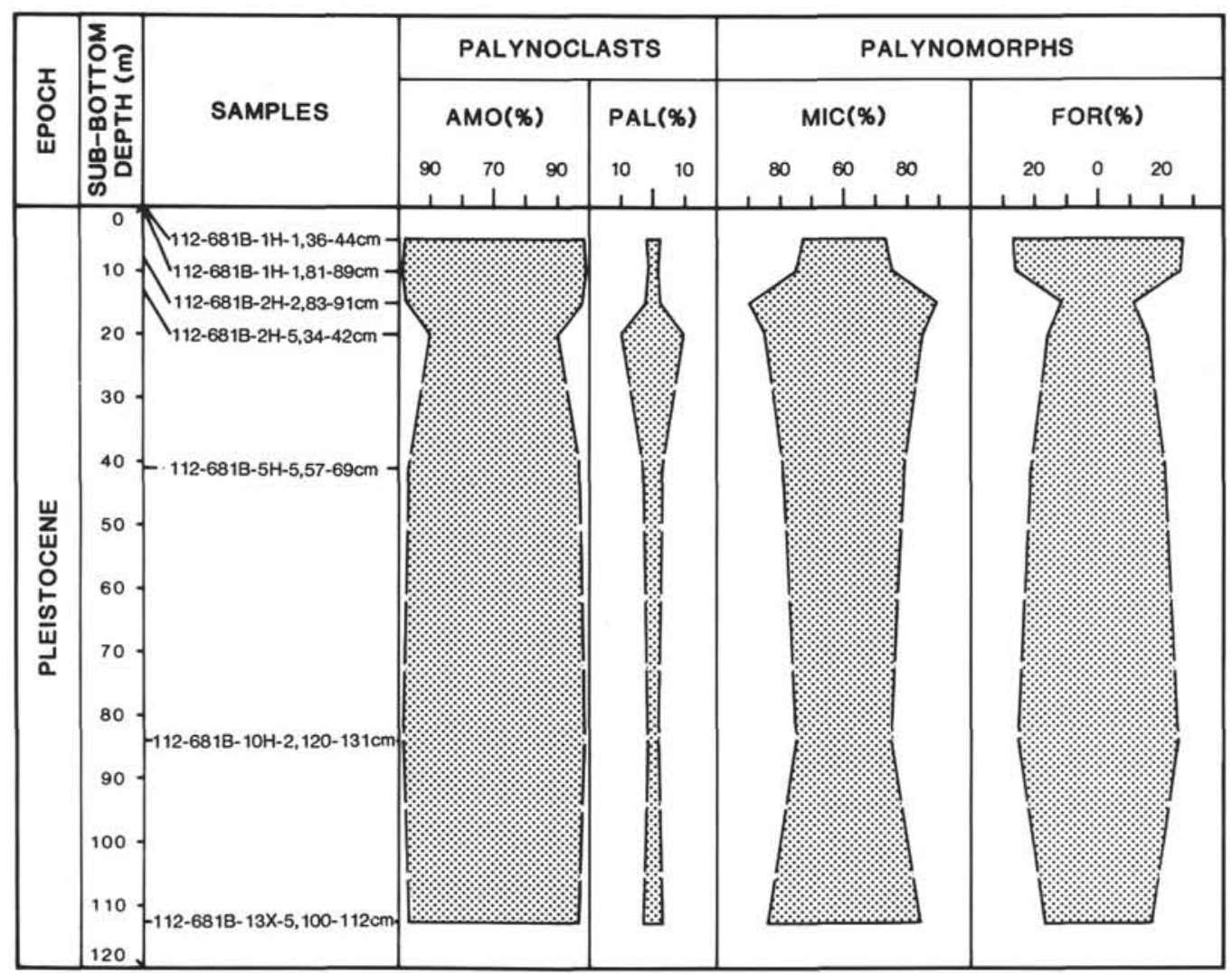

Figure 10. Palynofacies and palynomorph biofacies analysis of Hole 681B. AMO $=$ amorphogen; $\mathrm{PAL}=$ palynomorphs; $\mathrm{MIC}=$ microplankton; FOR = foraminiferal test linings. 


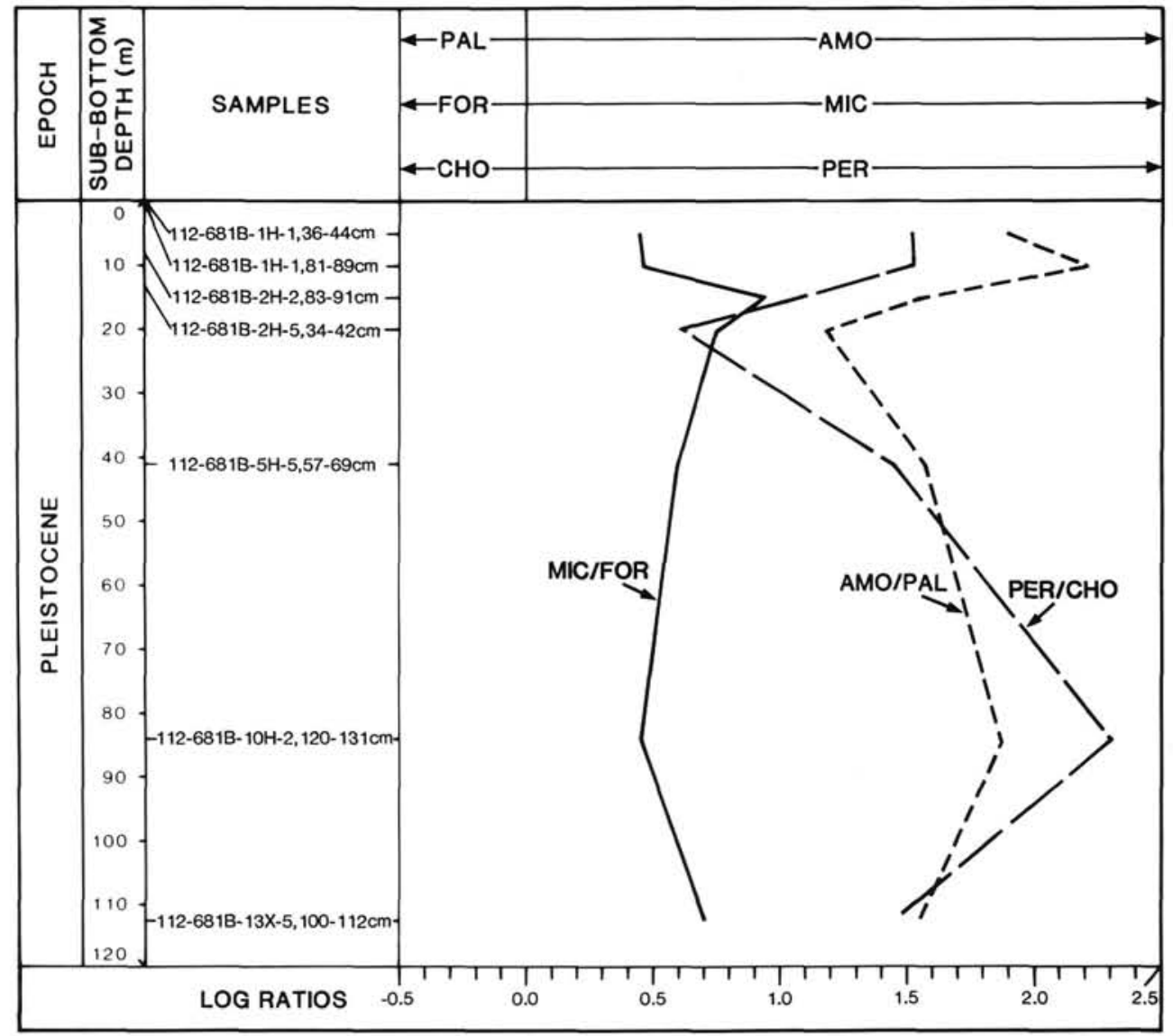

Figure 11. Palynoclast, palynomorph, and microplankton log ratios of Hole 681B. PAL $=$ palynomorphs; $\mathrm{AMO}=$ amorphogen; $\mathrm{FOR}=$ foraminiferal test linings; $\mathrm{MIC}=$ microplankton $; \mathrm{CHO}=$ chorate dinoflagellate cysts (G-cysts); PER = peridiniacean dinoflagellate cysts $(\mathrm{P}$-cysts); $\mathrm{AMO} / \mathrm{PAL}=$ amorphogen/palynomorphs log ratio; $\mathrm{MIC} / \mathrm{FOR}=$ microplankton/foraminiferal test linings log ratio; $\mathrm{PER} / \mathrm{CHO}=$ peridiniacean/chorate dinoflagellate cysts $(=\mathrm{P}$-cysts/G-cysts $) \log$ ratio.

No apparent relationship exists between trends in the AMO/PAL log ratio and the MIC/FOR (microplankton/foraminiferal test linings) and PER/CHO (peridiniacean/chorate dinoflagellate cysts $=$ P-cysts/G-cysts) log ratios depicted in Figure 20. Such trends were observed in other holes, e.g., Hole $686 \mathrm{~B}$, and their absence in Hole $687 \mathrm{~B}$ may reflect the erratic sample coverage.

\section{Hole 687B Palynomorph Biofacies}

Figure 19 demonstrates that a relative peak in abundance of foraminiferal test linings occurs in the upper 0.79 mbsf. A similar trend was observed in samples from other Leg 112 holes. Samples at 0.38 and $0.79 \mathrm{mbsf}$ contain average proportions of foraminiferal test linings ( $26 \%$ mean) for all studied samples. The level of foraminiferal test linings decreases in samples at 3.86 and $10.58 \mathrm{mbsf}$, but increases again at 47.31 and 53.32 mbsf ( $21.5 \%$ and $33.0 \%$, respectively). The deepest sample (160.89 mbsf) also contains more than $20 \%$ foraminiferal test linings. In contrast to observations from samples at other sites, these relatively high levels of foraminiferal test linings may be associated with bioturbated strata in Hole $687 \mathrm{~B}$. These trends are reflected in the variations in the $\mathrm{MIC} / \mathrm{FOR} \log$ ratio (Fig. 20) with low values of about 0.5 in the bioturbated sediments and high values of about 1.3 in the laminated strata.

\section{Hole 687B Microplankton Biofacies}

The stratigraphic distribution of the dinoflagellate cyst species appearing in the samples from Hole $687 \mathrm{~B}$ is summarized in Table 11. The microplankton assemblages are dominated by peridiniacean dinoflagellate cysts (P-cysts); these account for $84.5 \%$ of the assemblage, on average (Fig. 21). The most characteristic species of this part of the microplankton assemblage are Brigantedinium spp. and Selenopemphix spp. (notably $S$. quanta in the sample at 47.31 mbsf).

Acritarch levels are high in samples at 3.86, 19.58, 47.31, and 53.32 mbsf. However, many of these specimens may be unassigned peridiniacean dinoflagellate cysts (P-cysts).

Skolochorate and spiniferate dinoflagellate cyst (G-cysts) are present in notable quantities only at 0.79 and 3.86 mbsf ( $10.0 \%$ and $15.5 \%$, respectively). Spiniferites ramosus dominates this component of the assemblages, a feature that is typical of other Leg 112 sites.

Trends in the PER/CHO (= P-cysts/G-cysts) log ratio indicate a shift toward chorate dinoflagellate cysts (G-cysts) in the upper $20 \mathrm{~m}$ of the hole, i.e., within lithologic Unit IA. This trend parallels the shift toward increasing foraminiferal test linings in the same section (Fig. 20) and may be associated with bioturbated strata. 


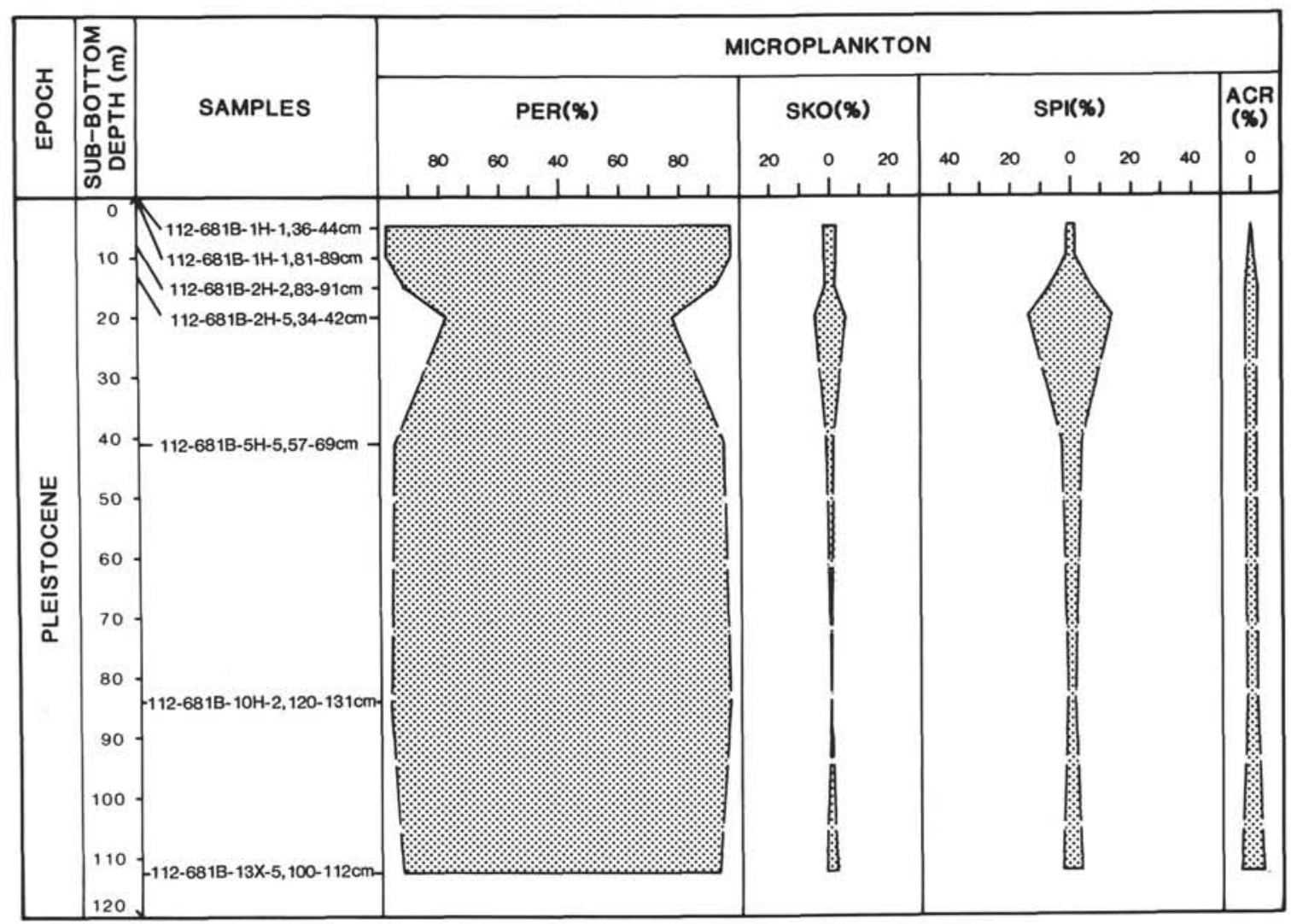

Figure 12. Microplankton biofacies analysis of Hole 681B. PER = peridiniacean dinoflagellate cysts (P-cysts); SKO = skolochorate dinoflagellate cysts (G-cysts); SPI = spiniferate dinoflagellate cysts (G-cysts); ACR = acritarchs.

\section{DISCUSSION}

Bearing in mind the small number of samples analyzed, the varying sample gaps, and the lack of quantitative data on palynoclast deposition rates, this study is to some extent unrepresentative. However, this study was only exploratory, and in this respect, has been successful. We made no attempt to answer specific questions because we were not sure what were appropriate questions. However, this study highlighted a number of important areas where future research, ideally within an integrated multidisciplinary atmosphere, will be required. Foundations have been laid for future palynological study into the upwelling system of the Peruvian continental margin.

When this study is completed, we hope that the results will be integrated with (1) organic geochemistry results to determine variations in organic supply and preservation through time and space, (2) lithology to ascertain the relationship with depositional environment, and (3) inorganic geochemistry results to deduce the relationships between depositional environment and organic-matter deposition and preservation.

\section{Palynofacies}

The palynoclast assemblages of all samples examined here are dominated overwhelmingly by amorphogen ( $96.5 \%$ mean), with low levels of palynomorphs (3.5\% mean). Hylogen and melanogen (woody and coaly material) are effectively absent from these assemblages, which indicates the lack of a terrestrial influx to the upwelling system of offshore Peru.

Fluctuations in the AMO/PAL (amorphogen/palynomorphs) $\log$ ratio (1.62 mean) are small in all holes studied. Little paleoenvironmental significance can be attached to the trends observed. However, two samples deviate from the general picture. First, the sample at 12.24 mbsf from Hole 681B contains higher than average levels of palynomorphs $(10.5 \%$ and an AMO/PAL log ratio of 0.92). This sample was derived from bioturbated sediments and contains below average levels of foraminiferal test linings $(15.5 \%)$ and slightly above average levels of G-cysts $(20.0 \%)$. Second, the sample from Hole 686B at $0.87 \mathrm{mbsf}$ has an even higher proportion of palynomorphs (15.0\% and an AMO/PAL log ratio of 0.75 ). This sample differs from the previous one in that it is from a laminated lithological unit. The palynomorph and microplankton components of this sample reveal abundant foraminiferal test linings $(50.0 \%)$ and G-cysts $(35.0 \%)$, respectively.

Thus, it would appear that when the AMO/PAL log ratio fluctuates, it is the variation in the palynomorph component of the ratio that is the most significant. The accumulation of large amounts of amorphogen, as in the samples studied here, has had the effect of swamping other palynoclast categories (which in this case are predominantly palynomorphs). Deposition of these high levels of amorphogen probably results from high productivity in the surface waters. Because samples derived from bioturbated sediments are indistinguishable, in terms of amorphogen levels, from samples taken from laminated units, the influence of anaerobic bottom conditions on palynoclast assemblage composition seems to have been slight. However, the levels of palynomorphs were diluted by amorphogen to such an extent that we can draw few meaningful conclusions from the nature of these assemblages.

The amount and nature of the amorphogen recovered during Leg 112 should relate to organic geochemistry from the point of view of assessing potential sources. Can variations in the nature of amorphogen be related to the hydrogen-richness of organic matter in the sediment? Mukhopadhyay (1986, p. 
Table 8. Dinoflagellate cyst species distribution list for Hole 681B.

\begin{tabular}{|c|c|c|c|c|c|c|c|}
\hline Samples & 1 & 2 & 3 & 4 & 5 & 6 & 7 \\
\hline \multicolumn{8}{|l|}{ G-cysts: } \\
\hline $\begin{array}{l}\text { Nematosphaeropsis labyrinthea } \\
\text { (Ostenfeld, 1900) Reid, } 1974\end{array}$ & - & $\mathrm{F}$ & $\mathrm{R}$ & - & $\mathbf{R}$ & - & - \\
\hline $\begin{array}{l}\text { Operculodinium centrocarpum } \\
\text { (Deflandre and Cookson, 1955) } \\
\text { Wall, } 1967\end{array}$ & - & - & $\mathrm{R}$ & - & - & $\mathbf{R}$ & - \\
\hline Spiniferites delicatus Reid, 1974 & - & $\mathbf{R}$ & $\mathrm{R}$ & $\mathrm{F}$ & - & - & - \\
\hline $\begin{array}{l}\text { Spiniferites hyperacanthus } \\
\text { (Deflandre and Cookson, 1955) } \\
\text { Cookson and Eisenack, } 1974\end{array}$ & - & R & R & $\mathrm{F}$ & $\mathbf{R}$ & $\mathbf{R}$ & R \\
\hline $\begin{array}{l}\text { Spiniferites membranaceus } \\
\text { (Rossignol, 1964) Sarjeant, } 1970\end{array}$ & - & - & $\mathrm{R}$ & $\mathbf{R}$ & $\mathrm{R}$ & - & - \\
\hline $\begin{array}{l}\text { Spiniferites mirabilis (Rossignol, } \\
\text { 1963) Sarjeant } 1970\end{array}$ & - & - & F & F & C & - & $\mathbf{R}$ \\
\hline $\begin{array}{l}\text { Spiniferites pachyderma (Rossignol, } \\
\text { 1964) Reid, } 1974\end{array}$ & - & $\mathrm{R}$ & $\mathrm{F}$ & F & $\mathrm{R}$ & $\mathrm{R}$ & $\mathbf{R}$ \\
\hline $\begin{array}{l}\text { Spiniferites ramosus (Ehrenberg, } \\
\text { 1838) Loeblich and Loeblich, } \\
1966\end{array}$ & - & C & F & $\mathrm{F}$ & $\mathrm{F}$ & $\mathrm{R}$ & A \\
\hline Spiniferites spp. undiff. & - & $\mathrm{R}$ & $\mathrm{F}$ & F & F & R & F \\
\hline \multicolumn{8}{|l|}{ P-cysts: } \\
\hline Brigantedinium & A & A & C & F & $\mathrm{F}$ & $\mathbf{R}$ & $\mathrm{F}$ \\
\hline caperatum Reid, 1977 & - & - & $\mathrm{R}$ & $\mathbf{R}$ & - & - & - \\
\hline aeroense Paulsen, 1905 & - & $\mathrm{R}$ & - & $\mathbf{R}$ & $\mathrm{F}$ & - & - \\
\hline $\begin{array}{l}\text { Protoperidinium americanum (Gran } \\
\text { and Braarud, 1935) Balech, } 1974\end{array}$ & $\mathrm{~F}$ & F & - & - & - & - & - \\
\hline $\begin{array}{l}\text { Quinquecuspis concretum (Reid, } \\
\text { 1977) Harland, } 1977\end{array}$ & $\mathrm{~F}$ & $\mathrm{~F}$ & $\mathrm{~F}$ & $\mathbf{R}$ & $\mathrm{F}$ & A & $\mathrm{C}$ \\
\hline Scrippsiella sp & - & - & $\mathrm{F}$ & $\mathrm{F}$ & $\mathrm{R}$ & $\mathbf{R}$ & $\mathbf{R}$ \\
\hline $\begin{array}{l}\text { Selenopemphix nephroides } \\
\text { Benedek, } 1972 \text { emend. Benedek } \\
\text { and Sarjeant, } 1981\end{array}$ & - & R & $\mathrm{F}$ & $\mathrm{F}$ & F & $\mathrm{R}$ & $\mathrm{F}$ \\
\hline $\begin{array}{l}\text { Selenopemphix quanta (Bradford, } \\
\text { 1975) Matsuoka, } 1986\end{array}$ & - & F & $\mathrm{F}$ & $\mathrm{F}$ & $\mathrm{F}$ & C & $\mathrm{F}$ \\
\hline $\begin{array}{l}\text { Trinovantedinium capitatum Reid, } \\
1977\end{array}$ & - & - & - & - & $\mathbf{R}$ & C & $\mathrm{R}$ \\
\hline Votadinium calvum Reid, 1977 & - & $\mathrm{R}$ & $\mathbf{R}$ & $\mathrm{F}$ & $\mathbf{R}$ & $\mathbf{R}$ & $\mathrm{R}$ \\
\hline Votadinium spinosum Reid, 1977 & $\mathrm{~F}$ & $\mathrm{~F}$ & - & - & - & - & - \\
\hline \multicolumn{8}{|l|}{ Other cysts: } \\
\hline & - & $\mathrm{R}$ & - & - & - & - & - \\
\hline Spiny forms & C & $\mathrm{F}$ & - & - & - & - & $\mathbf{R}$ \\
\hline
\end{tabular}

Sample $1=112-681 \mathrm{~B}-1 \mathrm{H}-1,36-44 \mathrm{~cm}(0.36 \mathrm{mbsf}) ; 2=112-681 \mathrm{~B}-1 \mathrm{H}-1,81-89$ $\mathrm{cm}(0.81 \mathrm{mbsf}) ; 3=112-681 \mathrm{~B}-2 \mathrm{H}-2,83-91 \mathrm{~cm}(8.23 \mathrm{mbsf}) ; 4=112-681 \mathrm{~B}-2 \mathrm{H}-5$, $34-42 \mathrm{~cm}(12.24 \mathrm{mbsf}) ; 5=112-681 \mathrm{~B}-5 \mathrm{H}-5,57-69 \mathrm{~cm}(40.97 \mathrm{mbsf}) ; 6=$ $112-681 \mathrm{~B}-10 \mathrm{H}-2,120-131 \mathrm{~cm}(84.60 \mathrm{mbsf}) ; 7=112-681 \mathrm{~B}-13 \mathrm{X}-5,100-112 \mathrm{~cm}$ $(112.50 \mathrm{mbsf}) ; \mathrm{R}=\operatorname{rare}(<3 \%) ; \mathrm{F}=$ few $(3 \%-15 \%) ; \mathrm{C}=\operatorname{common}(15 \%-30 \%)$; $\mathrm{A}=$ abundant $(>30 \%)$

113) stated that "Evaluation of amorphous organic matter requires thorough understanding of the different types of primary and secondary macerals and their hydrocarbon potential at different stages of maturation." Palynological study of amorphogen is an important part of such studies.

Gas-prone kerogens are deficient in hydrogen relative to oil-prone kerogens. As a result, gas-prone kerogens have higher specific gravities that can be measured (Kinghorn and Rahman, 1983). Such measurements might be usefully compared with palynological observations with the aim of distinguishing oil-prone amorphogen from gas-prone amorphogen.

Powell et al. (1982) reported that fluorescence may be used to distinguish different types of amorphogen. According to Kinghorn and Rahman (1983), hydrogen-rich, oil-prone amorphogens having lower specific gravities fluoresce, while gasprone types do not. We recommend that fluorescence techniques be used to investigate the nature of the amorphogen observed here.

\section{Palynomorph Biofacies}

Microplankton ( $73.5 \%$ mean) dominate the palynomorph assemblages, and are accompanied by subordinate quantities of foraminiferal test linings (26.5\% mean). For the sample suite as a whole, the MIC/FOR (microplankton/foraminiferal test linings) log ratio has a mean value of 0.55 .

Levels of foraminiferal test linings in samples from Hole $679 \mathrm{D}$ are particularly high, with a mean value of $42.5 \%$ and a $\mathrm{MIC} / \mathrm{FOR} \log$ ratio of 0.15 . These consistently augmented levels of foraminiferal test linings may be associated with deposition in anoxic or dysaerobic bottom-water conditions.

Foraminiferal test linings are also particularly well represented in the uppermost samples from Holes 680B, 681B, $686 \mathrm{~B}$, and $687 \mathrm{~B}$. The peak in foraminiferal test linings usually occurs at least in the upper $0.80 \mathrm{~m}$ and is characterized by a mean value of more than $30.0 \%$ and a $\mathrm{MIC} / \mathrm{FOR} \log$ ratio below 0.40 .

The shift in the youngest sediments toward foraminiferal test linings, at the expense of the microplankton, is especially well illustrated in Hole $686 \mathrm{~B}$. In this instance, foraminiferal test linings attain abundances of more than $20.0 \%(37.0 \%$ mean) in the upper $6.8 \mathrm{~m}$. In Hole $680 \mathrm{~B}$, the same trend (in the upper $5 \mathrm{~m}$ ) to some extent parallels fluctuations in the PER/ $\mathrm{CHO}$ (peridiniacean/chorate dinoflagellate cysts $=$ P-cysts G-cysts) and the AMO/PAL (amorphogen/palynomorphs) log ratios.

Without exception, all samples exhibiting the peak of foraminiferal test linings in the youngest sediments were derived from laminated sediments. However, the relationship between the MIC/FOR log ratio and sedimentation with respect to oxygen levels is not always clear. Evidence from Hole 687B, for example, shows that bioturbated sediments can also have high levels of foraminiferal test linings. Samples at 47.31 and 53.32 mbsf contain $21.5 \%$ and $33.0 \%$ foraminiferal test linings, respectively. Both samples were taken toward the base of bioturbated lithologic Unit IB.

Although foraminiferal test linings are particularly well represented in laminated sediments, another factor, independent of the strength of the upwelling system, may have had a greater controlling influence on the MIC/FOR log ratio.

Fluctuations in the paleotemperature of sea surface-water (reflecting glacial/interglacial cycles in Pleistocene time) can be calculated geochemically by measuring the relative abundances of di- and tri-unsaturated alkenones ( $U_{37}^{k}$ Index). Using this molecular parameter (Farrimond et al., this volume), one can see that the upper $16 \mathrm{~m}$ in Hole $686 \mathrm{~B}$ is characterized by a lowered water temperature (from about $26^{\circ}$ to about $18^{\circ} \mathrm{C}$ ). This body of sediments also contains the foraminiferal testlining peak (upper $6.8 \mathrm{~m}$ ) in this hole. Therefore, surfacewater temperature, related to the strength of the upwelling, may have been the most significant factor controlling the abundance of foraminiferal test linings relative to the levels of microplankton.

Foraminiferal test linings consist of labile organic compounds (amino acids and sugars), which are effectively degraded during microbial attack (K.-C. Emeis, pers. comm., 1989). The decreasing abundance of foraminiferal test linings may be caused by this progressive degradation. In a sulfatereducing environment below the sediment/water interface, the carbonate parts of foraminifer tests are dissolved and the polysaccharide or protein linings are exposed to microbial attack. According to K.-C. Emeis (pers. comm., 1989), the amounts of sugars and amino acids decrease exponentially from the surface (where they contribute up to $30 \%$ of the total organic carbon) to about 40 mbsf (where they contribute less than $1 \%$ of the total organic carbon).

Foraminiferal test linings are ontogenetic records, and as Brummer et al., (1986, p. 52) stated, “. . . ontogenetic morphology allows the identification of pre-adult forms which constitute the bulk of a foraminiferal sample." These linings 


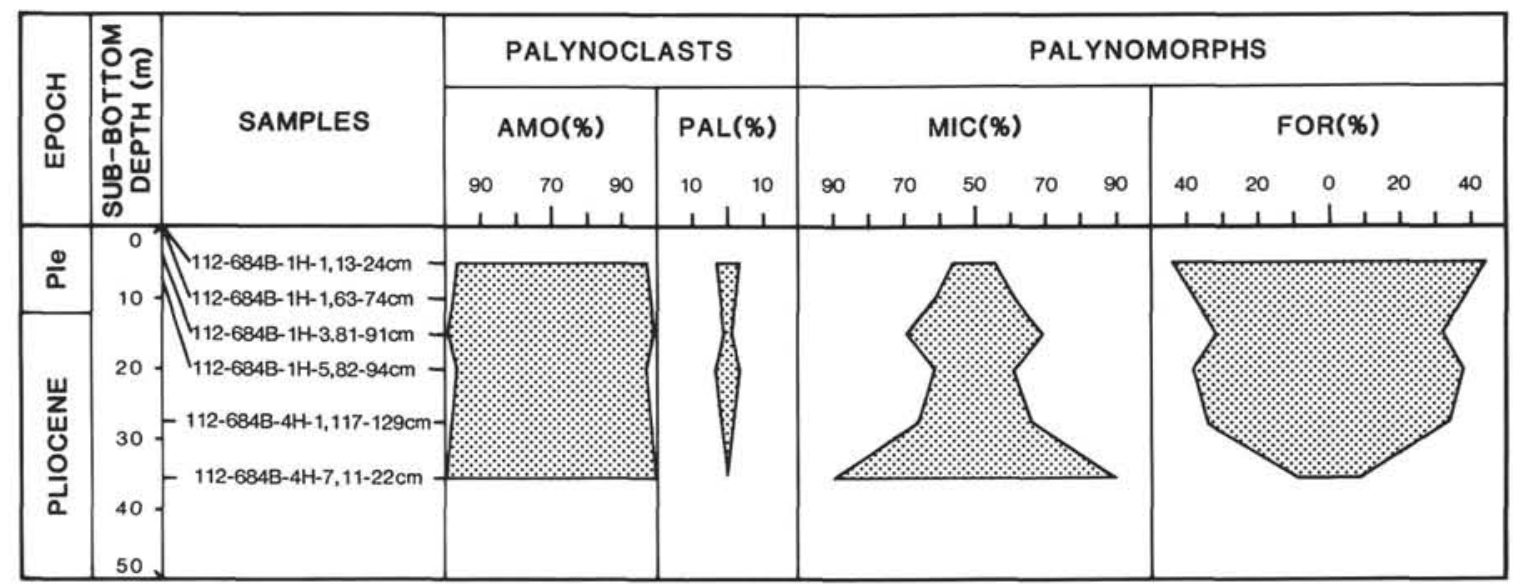

Figure 13. Palynofacies and palynomorph biofacies analysis of Hole $684 \mathrm{~B} . \mathrm{AMO}=$ amorphogen; $\mathrm{PAL}=$ palynomorphs; MIC $=$ microplankton; FOR $=$ foraminiferal test linings.

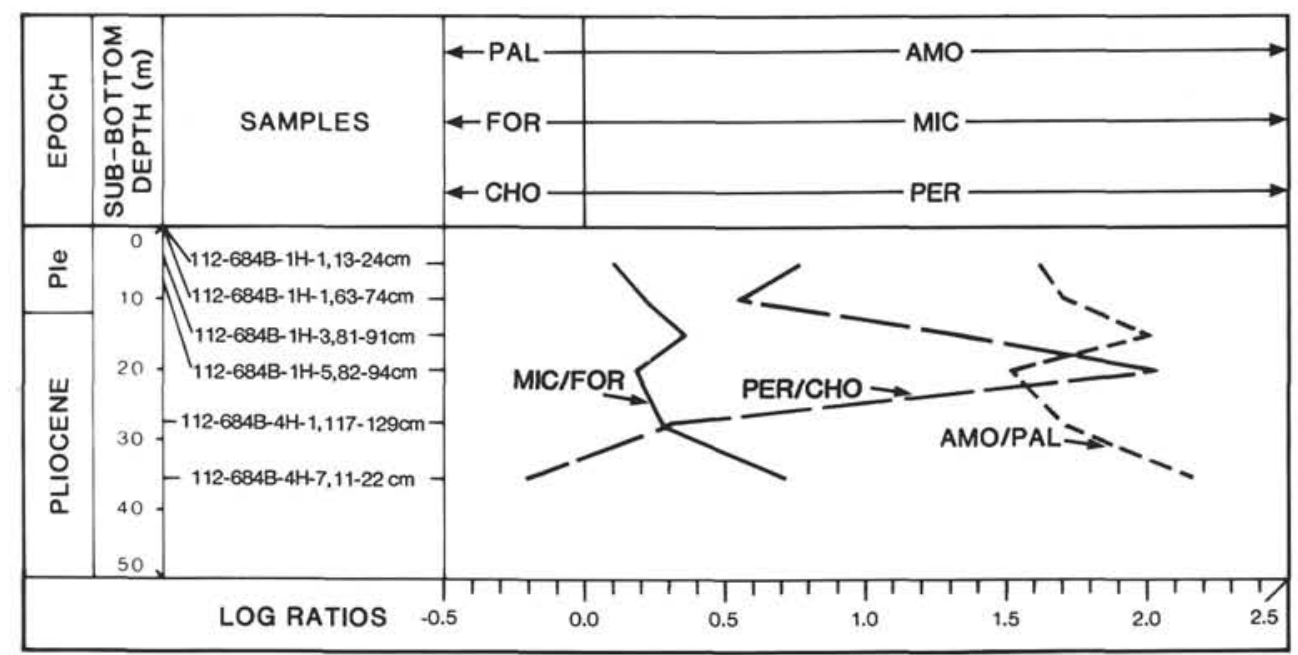

Figure 14. Palynoclast, palynomorph, and microplankton log ratios of Hole 684B. PAL = palynomorphs; $\mathrm{AMO}=$ amorphogen; $\mathrm{FOR}=$ foraminiferal test linings; $\mathrm{MIC}=$ microplankton; $\mathrm{CHO}=$ chorate dinoflagellate cysts (G-cysts); PER = peridiniacean dinoflagellate cysts (P-cysts); AMO/PAL = amorphogen/palynomorphs log ratio; $\mathrm{MIC} / \mathrm{FOR}=$ microplankton/foraminiferal test linings log ratio; $\mathrm{PER} / \mathrm{CHO}=$ peridiniacean/chorate dinoflagellate cysts $(=\mathrm{P}$-cysts/G-cysts $) \log$ ratio.

have potential uses in paleoenvironmental analysis and biocorrelation. Scanning electron microscopy would probably be essential. The foraminiferal test linings recorded and studied here are sufficiently abundant and well-preserved to make them ideal for such an investigation.

\section{Microplankton Biofacies}

When all samples studied here are considered as a whole, one can see that P-cysts ( $81.5 \%$ mean) dominate the G-cysts (17.0\% mean), with low representation of acritarchs $(1.5 \%$ mean). The mean value of the PER/CHO log ratio is 0.96 .

For example, in Hole 679D, P-cysts occur in above average quantities of $86.0 \%$ and a mean PER/CHO (= P-cysts/G-cysts) $\log$ ratio of 0.96 . Levels in Hole 684B are even higher, with P-cysts at a mean of $93.0 \%$ and a microplankton log ratio at a mean of 1.41. In both holes, the assemblages were collected from unbioturbated sediments, indicating the relationship between upwelling and the dominance of P-cysts, first observed in modern sediments from off Pisco by Wall et al. (1977).
Why should P-cysts be dominant in the upwelling system? The evidence of Wall et al. (1977) suggests that a close relationship exists between the abundance of P-cysts and relatively cooler surface-water temperatures. The intensity of upwelling can be measured by the temperature of surface waters.

Samples from Hole 686B show that P-cysts reach a peak abundance within the uppermost samples, notably the sample at $3.79 \mathrm{mbsf}$, where a value of $97.5 \%$ was observed. This peak appears to correlate with a minimum in geochemically evaluated temperatures ( $U_{37}^{\mathrm{k}}$ Index) in surface waters, indicating cool waters of about $20^{\circ} \mathrm{C}$ (Farrimond et al., this volume). This trend may be related to a combination of differing factors, including glacial/interglacial cyclicity and the strength of the local upwelling.

The clear relationship between unbioturbated, laminated sediments and the dominance of P-cysts is noticeable in many of the samples analyzed. G-cysts tend to be more common, but not necessarily dominant, in the bioturbated strata, i.e., sediments characterized by deposition outside the influence of 
Table 9. Dinoflagellate cyst species distribution list for Hole 684B.

\begin{tabular}{|c|c|c|c|c|c|c|}
\hline Samples & 1 & 2 & 3 & 4 & 5 & 6 \\
\hline $\begin{array}{l}\text { G-cysts: } \\
\text { Impagidinium aculeatum (Wall, } \\
\text { 1967) Harland, } 1983\end{array}$ & - & $\mathrm{R}$ & - & $\mathrm{F}$ & $\mathrm{F}$ & $\mathrm{F}$ \\
\hline $\begin{array}{l}\text { Lingulodinium machaerophorum } \\
\text { (Deflandre and Cookson, 1955) } \\
\text { Wall, } 1967\end{array}$ & - & - & - & $\mathrm{R}$ & - & \\
\hline $\begin{array}{l}\text { Melitasphaeridium choanophorum } \\
\text { (Deflandre and Cookson, 1955) } \\
\text { Harland and Hill, } 1979\end{array}$ & - & - & - & $\mathrm{R}$ & - & $\mathbf{R}$ \\
\hline $\begin{array}{l}\text { Nematosphaeropsis labyrinthea } \\
\text { (Ostenfeld, 1900) Reid, } 1974\end{array}$ & $\mathrm{R}$ & - & - & - & $\mathbf{R}$ & \\
\hline $\begin{array}{l}\text { Operculodinium centrocarpum } \\
\text { (Deflandre and Cookson, 1955) } \\
\text { Wall, } 1967\end{array}$ & C & $\mathrm{C}$ & $\mathrm{R}$ & $\mathbf{R}$ & A & \\
\hline $\begin{array}{l}\text { Spiniferites hyperacanthus } \\
\text { (Deflandre and Cookson, 1955) } \\
\text { Cookson and Eisenack, 1974 }\end{array}$ & - & $\mathbf{R}$ & $\mathrm{R}$ & - & R & \\
\hline $\begin{array}{l}\text { Spiniferites membranaceus } \\
\quad \text { (Rossignol, 1964) Sarjeant, } 1970\end{array}$ & - & $\mathbf{R}$ & - & - & - & \\
\hline $\begin{array}{l}\text { Spiniferites mirabilis (Rossignol, } \\
\text { 1963) Sarjeant, } 1970\end{array}$ & $\mathbf{R}$ & $\mathbf{R}$ & $\mathrm{F}$ & - & $\mathrm{F}$ & \\
\hline $\begin{array}{l}\text { Spiniferites ramosus (Ehrenberg, } \\
\text { 1838) Loeblich and Loeblich, } 1966\end{array}$ & F & F & F & F & A & \\
\hline Spiniferites spp. undiff. & R & F & R & R & $\mathbf{R}$ & \\
\hline P-cysts: & & & & & & \\
\hline & $\begin{array}{l}C \\
R\end{array}$ & C & $\begin{array}{l}A \\
F\end{array}$ & $\stackrel{A}{-}$ & F & \\
\hline Peridir & $\mathrm{F}$ & $\mathrm{F}$ & $\mathbf{R}$ & - & F & \\
\hline $\begin{array}{l}\text { Protoperidinium americanum (Gran } \\
\text { and Braarud, 1935) Balech, } 1974\end{array}$ & - & - & $\mathrm{R}$ & $\mathrm{R}$ & - & \\
\hline $\begin{array}{l}\text { Quinquecuspis concretum (Reid, } \\
\text { 1977) Harland, } 1977\end{array}$ & $\mathrm{R}$ & $\mathrm{F}$ & $\mathrm{R}$ & $\mathrm{R}$ & - & \\
\hline Scrippsiella spp. undiff. & $\mathrm{F}$ & $\mathrm{R}$ & $\mathrm{R}$ & $\mathbf{R}$ & $\mathrm{R}$ & \\
\hline $\begin{array}{l}\text { Selenopemphix nephroides Benedek, } \\
1972 \text { emend. Benedek and } \\
\text { Sarjeant, } 1981\end{array}$ & - & $\mathrm{R}$ & $\mathrm{R}$ & $\mathrm{R}$ & - & \\
\hline $\begin{array}{l}\text { Selenopemphix quanta (Bradford, } \\
\text { 1975) Matsuoka, } 1986\end{array}$ & $\mathrm{~F}$ & $\mathrm{~F}$ & $\mathrm{~F}$ & $\mathrm{~F}$ & $\mathrm{~F}$ & $\mathbf{R}$ \\
\hline $\begin{array}{l}\text { Trinovantedinium capitatum Reid, } \\
1977\end{array}$ & $\mathrm{R}$ & $\mathbf{R}$ & - & - & - & \\
\hline Votadinium calvum Reid, 1977 & $\mathbf{R}$ & $\mathbf{R}$ & $\mathbf{R}$ & - & - & - \\
\hline & & & & & & \\
\hline $\begin{array}{l}\text { Polykrikos schwartzii Butschli, } 1873 \\
\text { Spiny forms }\end{array}$ & $\bar{R}$ & $\bar{R}$ & $\bar{R}$ & $\begin{array}{l}\mathrm{R} \\
\mathrm{R}\end{array}$ & - & \\
\hline
\end{tabular}

Sample $1=112-684 \mathrm{~B}-1 \mathrm{H}-1,13-24 \mathrm{~cm}(0.13 \mathrm{mbsf}) ; 2=112-684 \mathrm{~B}-1 \mathrm{H}-1$, $63-74 \mathrm{~cm}(0.63 \mathrm{mbsf}) ; 3=112-684 \mathrm{~B}-1 \mathrm{H}-3,81-91 \mathrm{~cm} \mathrm{(3.81} \mathrm{mbsf);4}=$ $112-684 \mathrm{~B}-1 \mathrm{H}-5,82-94 \mathrm{~cm}(6.82 \mathrm{mbsf}) ; 5=112-684 \mathrm{~B}-4 \mathrm{H}-1,117-129 \mathrm{~cm}$ $(27.67 \mathrm{mbsf}) ; 6=112-684 \mathrm{~B}-4 \mathrm{H}-7,11-22 \mathrm{~cm}(35.61 \mathrm{mbsf}) ; \mathrm{R}=$ rare $(<3 \%) ;$ $\mathrm{F}=$ few $(3 \%-15 \%) ; \mathrm{C}=$ common $(15 \%-30 \%) ; \mathrm{A}=$ abundant $(>30 \%)$.

the oxygen-minimum layer. The PER/CHO (= P-cysts/Gcysts) $\log$ ratio tends to decrease in bioturbated strata. Spiniferate species (G-cysts) tend to vary in abundance within these samples and are usually more common than skolochorate species (also G-cysts). Thus, if G-cysts are more common, Spiniferites spp., rather than Operculodinium centrocarpum, tend to dominate the G-cyst assemblages. However, the relationship between bioturbated strata and decreased levels of P-cysts is not always clear, indicating the possible influence of other factors.

For example, the upper five samples from Hole $680 \mathrm{~B}$ are from laminated units, yet for the hole as a whole (six samples), P-cysts have a mean representation of only $76.0 \%$ and a microplankton log ratio of 00.61 . This apparently anomalous situation does not necessarily indicate that oceanographic influences at Site 680 were different from those at other sites. A situation such as this is hampered by the large sample gaps. The low levels of P-cysts at this site may be explained by the fact that the deepest sample at 89.88 mbsf contains only $48.5 \%$ P-cysts. Similarly, the dinoflagellate cyst assemblages within samples of Pliocene age in Hole 684B contrast with those from Pleistocene-age samples. Two samples from the bioturbated Pliocene strata have P-cyst levels of $64.5 \%$ and $36.5 \%$ and correspondingly low microplankton ratios.

Other subtle variations in the dinoflagellate cyst log ratio exist and are more difficult to explain on the basis of this data base. For example, samples at 40.97 and $84.60 \mathrm{mbsf}$ from Hole $681 \mathrm{~B}$ are from a mixed succession of terrigenous and diatomaceous muds. These samples have high P-cyst levels.

Detailed study of variations in dinoflagellate cyst assemblages offers us the greatest hope for palynological characterization of upwelling systems. We recommend that a single hole (Hole 686B) be examined having closely spaced samples (see Lewis et al., this volume) and in close conjunction with other disciplines, notably organic geochemistry. Ideally, the results of our study should be interpreted not only from the point of view of the local upwelling system, but also in terms of glacial/nonglacial cyclicity, organic matter composition, productivity, and upwelling dynamics.

The upwelling system of offshore Peru could be used as a model for interpreting older Cenozoic sediments, where P-cysts occur with diatom-rich assemblages. For example, it would be interesting to investigate the relationship between the abundance of peridiniacean dinoflagellate cysts in the early Eocene Balder Formation of the North Sea Basin (the Deflandrea oebisfeldensis Acme of Knox and Harland, 1979) and the accompanying diatom-rich floras. While D. oebisfeldensis belongs to a family different from the peridiniacean species typical in this study, all are P-cyst types in the widest sense (i.e., belonging to the suborder Peridiniineae). Therefore, it would be interesting to speculate that the thecate, motile peridiniacean species of the Balder Formation preyed on diatoms in much the same way as scientists believe that the peridiniacean species do in the upwelling system of offshore Peru. As Harland (1988, p. 113) stated, ". . . two entirely separate feeding strategies exist within the dinoflagellates, and this has potential for use in the interpretation of the fossil record. Perhaps most dinoflagellates of gonyaulacacean affinity are autotrophs, whereas many peridiniacean forms are heterotrophs."

\section{CONCLUSIONS}

\section{Palynofacies}

In the 40 samples analyzed, the palynoclast assemblages are strongly dominated by amorphogen. Little terrigenous influx is evident in the form of hylogen, melanogen, or miospores.

The levels of amorphogen swamp other palynoclast categories, and little significance can be attached to any variations observed. A vague relationship may indicate lower levels of amorphogen at times of weak or absent upwelling. However, palynological processing techniques could be equally responsible for such trends.

\section{Palynomorph Biofacies}

Palynomorph assemblages are dominated by microplankton having varying levels of subordinate foraminiferal test linings. Miospores are poorly represented and are absent from most samples, which confirms the low levels of terrestrial influx to the marine realm.

Foraminiferal test linings are particularly abundant in the shallowest samples in the holes examined, which may reflect low surface-water paleotemperatures. High percentage levels of foraminiferal test linings often parallel high levels of peridiniacean dinoflagellate cysts (P-cysts). However, this is not always true, and where foraminiferal test linings are poorly represented, P-cysts may be abundant. 


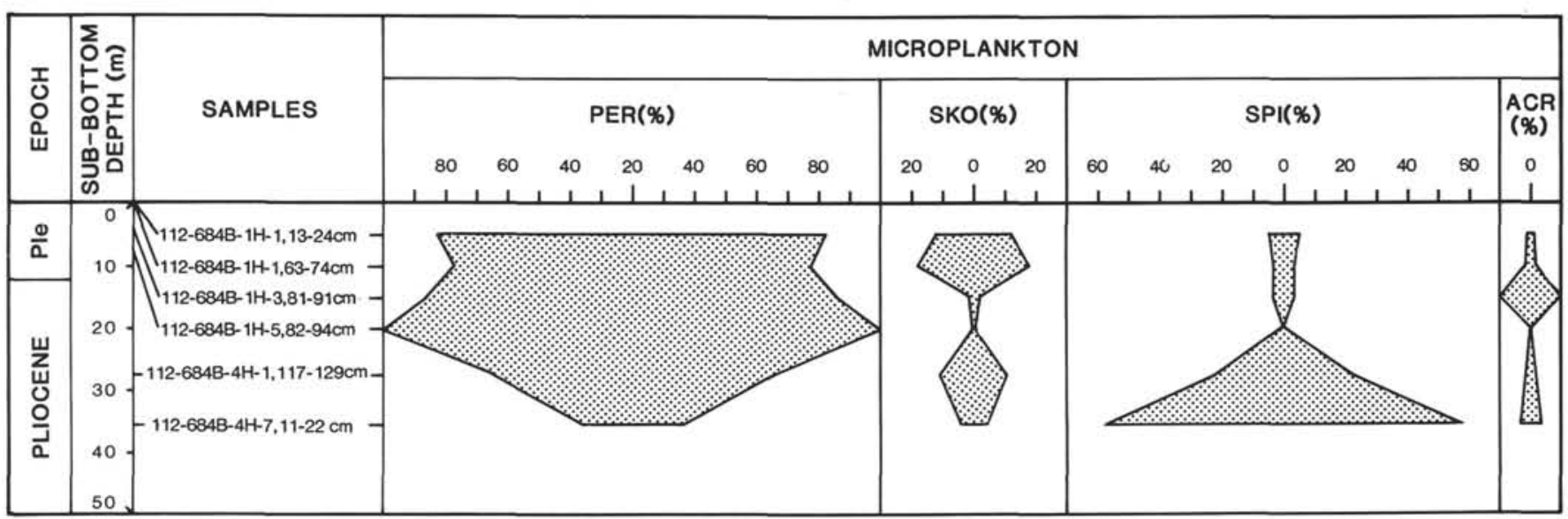

Figure 15. Microplankton biofacies analysis of Hole 684B. PER = peridiniacean dinoflagellate cysts (P-cysts); $\mathrm{SKO}=$ skolochorate dinoflagellate cysts (G-cysts); SPI = spiniferate dinoflagellate cysts (G-cysts); ACR = acritarchs.

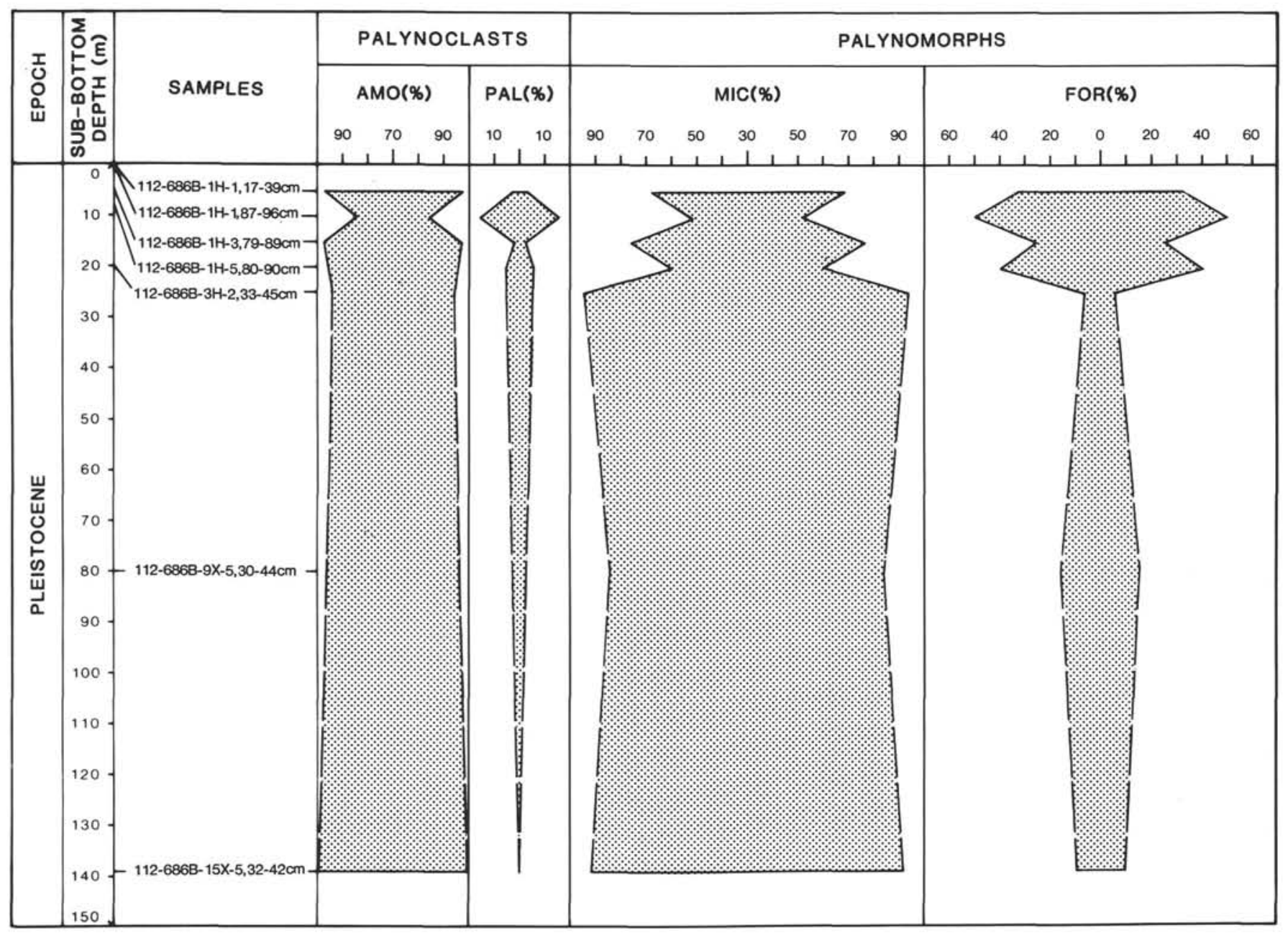

Figure 16. Palynofacies and palynomorph biofacies analysis of Hole $686 \mathrm{~B} . \mathrm{AMO}=$ amorphogen; $\mathrm{PAL}=$ palynomorphs; $\mathrm{MIC}=$ microplankton; $\mathrm{FOR}=$ foraminiferal test linings. 


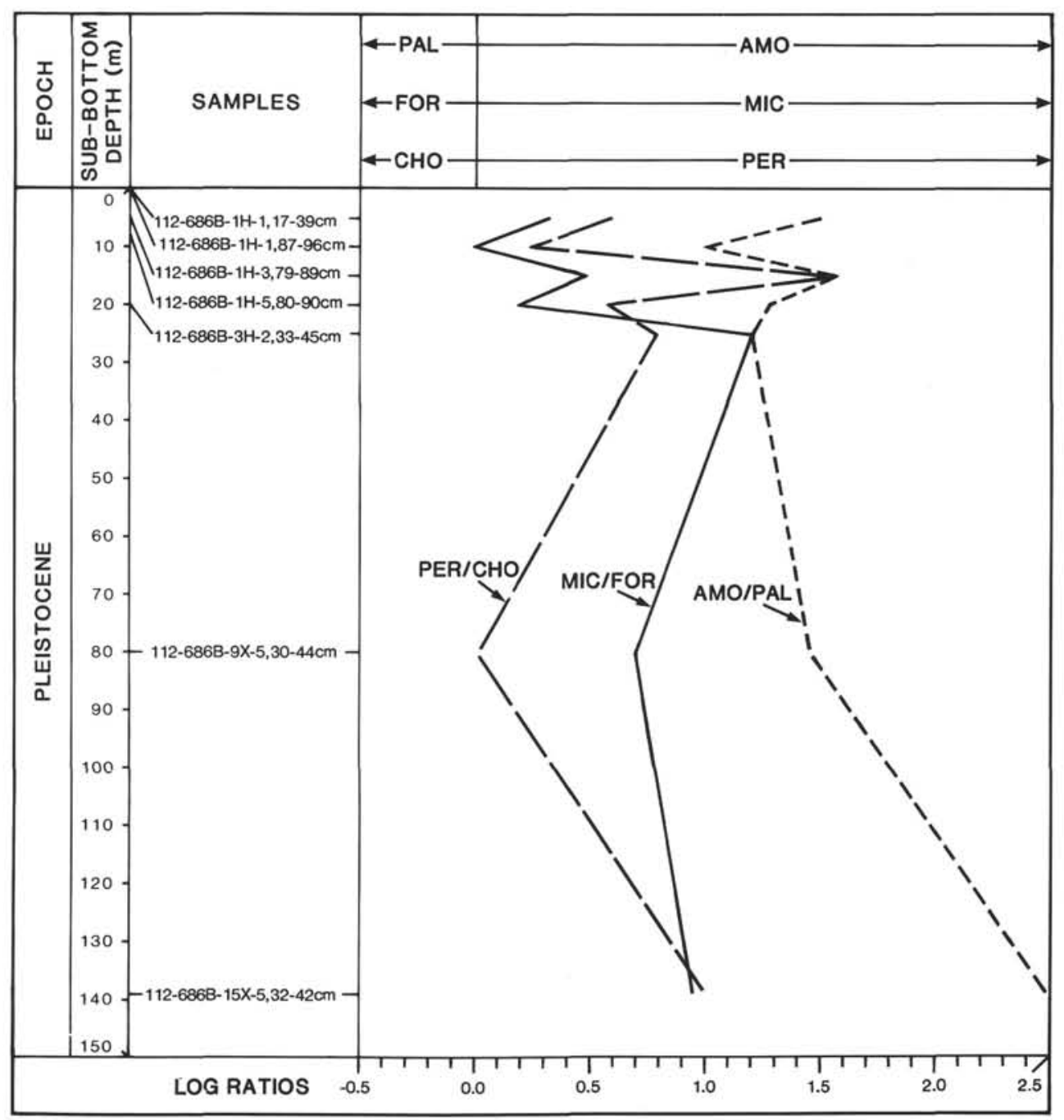

Figure 17. Palynoclast, palynomorph, and microplankton log ratios of Hole 686B. PAL $=$ palynomorphs; $\mathrm{AMO}=$ amorphogen $; \mathrm{FOR}=$ foraminiferal test linings; $\mathrm{MIC}=$ microplankton; $\mathrm{CHO}=$ chorate dinoflagellate cysts (G-cysts); PER = peridiniacean dinoflagellate cysts (P-cysts); $\mathrm{AMO} / \mathrm{PAL}=$ amorphogen/palynomorphs log ratio; $\mathrm{MIC} / \mathrm{FOR}=$ microplankton/foraminiferal test linings log ratio; $\mathrm{PER} / \mathrm{CHO}=$ peridiniacean/chorate dinoflagellate cysts (= P-cysts/G-cysts) log ratio.

\section{Microplankton Biofacies}

Microplankton assemblages are dominated by peridiniacean dinoflagellate cysts (P-cysts) having varying levels of gonyaulacacean dinoflagellate cysts (G-cysts). Acritarchs are rare; many may be small, spinose, and as yet unidentified P-cysts.

The dominance of P-cysts is equated with derivation of samples from laminated, unbioturbated units deposited under the influence of upwelling in the oxygen-minimum zone. The dominance of G-cysts, or the depressed dominance of P-cysts, is associated with samples from unlaminated, bioturbated units.

The ratio of P-cysts to G-cysts appears to indicate the varying strength of upwelling.

\section{ACKNOWLEDGMENTS}

We thank Kay-Christian Emeis, Peta Mudie, and an anonymous reviewer for reading the manuscript and for their constructive criticisms. J. D. Dodge and Jane Lewis acknowledge receipt of Natural Environment Research Council Grant GST/02/246. The initial research for this study was conducted by Nicholas Butler under tenureship of the same grant. We thank the staff of the Palynology Laboratory and Drawing Office at the Sunbury Research Centre of BP
Research. This paper is published with the permission of British Petroleum Company plc.

\section{REFERENCES}

Bostick, N. H., 1971. Thermal alteration of clastic organic particles as an indicator of contact and burial metamorphism in sedimentary rocks. Geosci. Man, 3:83-92.

Brummer, G.-J.A., Hemleben, C., and Spindler, M., 1986. Planktonic foraminiferal ontogeny and new perspectives for micropalaeontology. Nature, 319:50-52.

Dale, B., 1976. Cyst formation, sedimentation, and preservation: factors affecting dinoflagellate assemblages in recent sediments from Trondheimsfjord, Norway. Rev. Palaeobot. Palynol., 22(1):39-60.

Durand, B., 1980. Sedimentary organic matter and kerogen. Definition and quantitative importance of kerogen. In Durand, B. (Ed.), Kerogen, Insoluble Organic Matter From Sedimentary Rocks: Paris (Editions Technip), 13-24.

Harland, R., 1988. Dinoflagellates, their cysts and Quaternary stratigraphy. New Phytol., 108:111-120.

Kinghorn, R.R.F., and Rahman, M., 1983. Specific gravity as a kerogen type and maturation indicator with special reference to amorphous kerogens. J. Petrol. Geol., 6 (2):179-194. 
Knox, R.W.O'B., and Harland, R., 1979. Stratigraphical relationships of the early Paleogene ash-series of NW Europe. J. Geol. Soc. (London), 136:463-470.

Manum, S. B., 1976. Dinocysts in Tertiary Norwegian-Greenland Sea sediments (Deep Sea Drilling Project Leg 38), with observations on palynomorphs and palynodebris in relation to environment. In Talwani, M., Udintsev, G., et al., Init. Repts. $D S D P, 38$ : Washington (U.S. Govt. Printing Office), 897-919.

Mukhopadhyay, P. K., 1986. A new classification for the organic components of kerogen: discussion. J. Petrol. Geol., 9 (1):111114.

Powell, T. G., Creaney, S., and Snowdon, L. R., 1982. Limitations of use of organic petrographic techniques for identification of petroleum source rocks. AAPG Bull., 66 (4):430-435.

Reading, H. G., 1978. Facies. In Reading H. G. (Ed.), Sedimentary Environments and Facies: Oxford (Blackwell), 4-14.

Rojas de Mendiola, B., 1981. Seasonal phytoplankton distribution along the Peruvian coast. In Richards, F. A. (Ed.), Coastal Upwelling: Alexandria (Am. Geophys. Union), 348-356.

Suess, E., von Huene, R., et al., 1987. Leg 112 studies continental margin. Geotimes, 32 (5):10-12.

1988. Proc. ODP, Init. Repts., 112: College Station, TX (Ocean Drilling Program).
Traverse, A., and Ginsburg, R. N., 1966. Palynology of the surface sediments of Great Bahama Bank, as related to water movement and sedimentation. In Manten, A. A. (Ed.), Marine Palynology: Mar. Geol., 4(6):417-459.

Tyson, R. V., 1987. The genesis and palynofacies characteristics of marine petroleum source rocks. In Brooks, J., and Fleet, A. J. (Eds.), Marine Petroleum Source Rocks: London (Geol. Soc. London), Spec. Publ. 26:47-67.

von Huene, R., Suess, E., and Emeis, K.-C., 1987. Convergent tectonics and coastal upwelling: A history of the Peru continental margin. Episodes, 10(2):87-93.

Wall, D., Dale, B., Lohmann, G. P., and Smith, W. K., 1977. The environmental and climatic distribution of dinoflagellate cysts in modern sediments from regions in the North and South Atlantic oceans and adjacent sea. Mar. Micropaleontol., 2:121-200.

Date of initial receipt: 13 September 1988

Date of acceptance: 1 June 1989

Ms. 112B-196

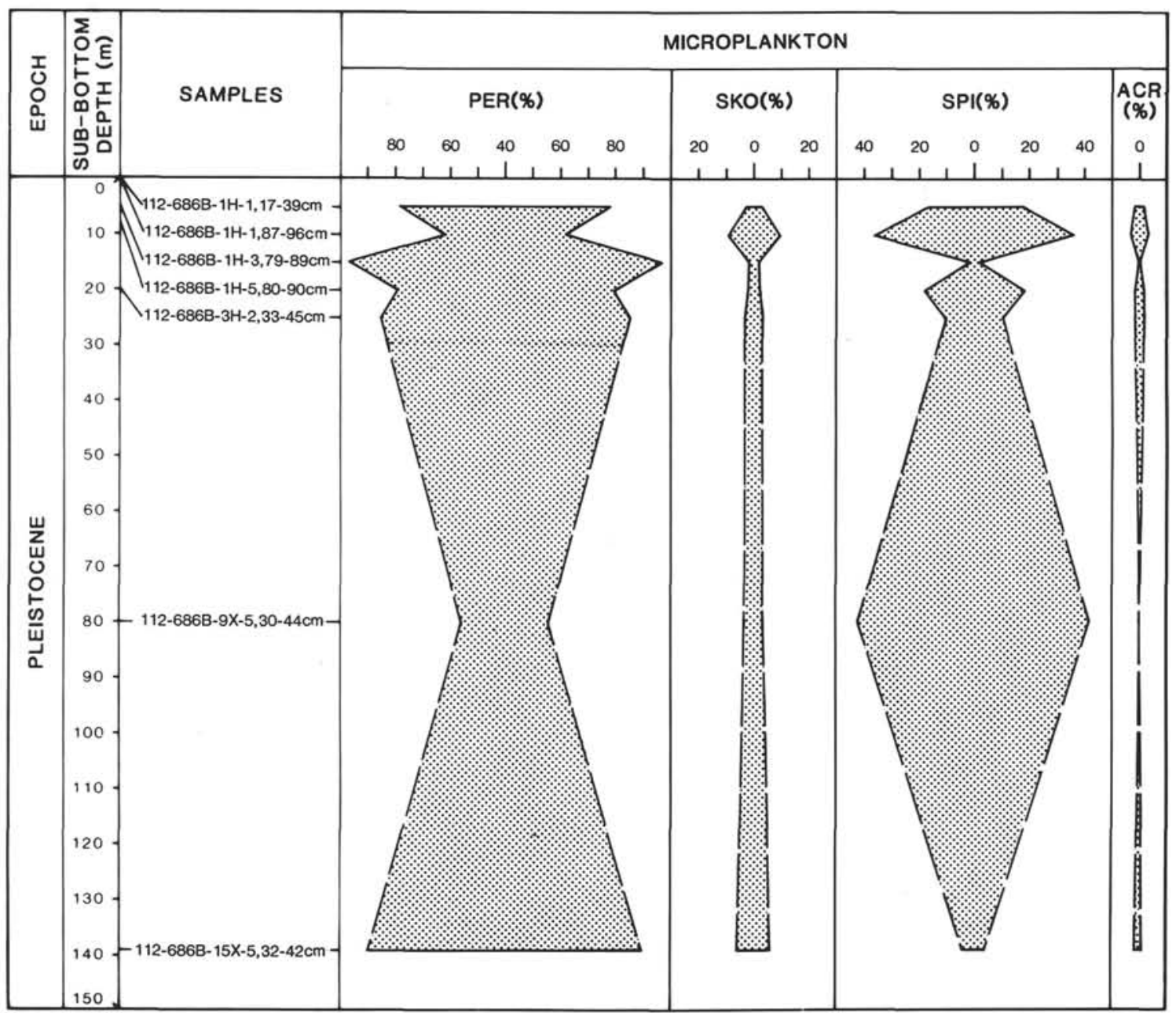

Figure 18. Microplankton biofacies analysis of Hole 686B. PER = peridiniacean dinoflagellate cysts (P-cysts); $\mathrm{SKO}=$ skolochorate dinoflagellate cysts (G-cysts); SPI = spiniferate dinoflagellate cysts (G-cysts); ACR = acritarchs. 
Table 10. Dinoflagellate cyst species distribution list for Hole 686B.

\begin{tabular}{|c|c|c|c|c|c|c|c|}
\hline Samples & 1 & 2 & 3 & 4 & 5 & 6 & 7 \\
\hline \multicolumn{8}{|l|}{ G-cysts: } \\
\hline $\begin{array}{l}\text { Impagidinium aculeatum (Wall, } \\
\text { 1967) Harland, } 1983\end{array}$ & - & - & - & $\mathrm{R}$ & $\mathbf{R}$ & - & - \\
\hline $\begin{array}{l}\text { Lingolodinium machaerophorum } \\
\text { (Deflandre and Cookson, 1955) } \\
\text { Wall, } 1967\end{array}$ & - & - & $\mathbf{R}$ & - & - & - & - \\
\hline $\begin{array}{l}\text { Nematosphaeropsis labyrinthea } \\
\text { (Ostenfeld, 1900) Reid, } 1974\end{array}$ & $\mathbf{F}$ & $\mathrm{F}$ & 一 & $\mathbf{R}$ & $\mathbf{R}$ & - & - \\
\hline $\begin{array}{l}\text { Operculodinium centrocarpum } \\
\text { (Deflandre and Cookson, 1955) } \\
\text { Wall, } 1967\end{array}$ & - & $\mathrm{R}$ & - & $\mathrm{R}$ & $\mathbf{R}$ & $\mathbf{R}$ & $\mathbf{R}$ \\
\hline $\begin{array}{l}\text { Spiniferites hyperacanthus } \\
\text { (Deflandre and Cookson, 1955) } \\
\text { Cookson and Eisenack, } 1974\end{array}$ & $\mathrm{R}$ & - & 一 & $\mathbf{R}$ & $\mathrm{R}$ & $\mathrm{R}$ & 一 \\
\hline $\begin{array}{l}\text { Spiniferites membranaceus } \\
\text { (Rossignol, 1964) Sarjeant, } 1970\end{array}$ & $\mathrm{R}$ & $\mathbf{R}$ & - & $\mathbf{R}$ & - & $\mathbf{R}$ & - \\
\hline $\begin{array}{l}\text { Spiniferites mirabilis (Rossignol, } \\
\text { 1963) Sarjeant, } 1970\end{array}$ & $\mathrm{~F}$ & $\mathrm{C}$ & - & $\mathrm{F}$ & $\mathrm{F}$ & $\mathrm{F}$ & $\mathbf{R}$ \\
\hline $\begin{array}{l}\text { Spiniferites pachyderma (Rossignol, } \\
\text { 1964) Reid, } 1974\end{array}$ & - & $\mathbf{R}$ & - & $\mathrm{F}$ & R & - & 一 \\
\hline $\begin{array}{l}\text { Spiniferites ramosus (Ehrenberg, } \\
\text { 1838) Loeblich and Loeblich, } 1966\end{array}$ & $\mathbf{F}$ & $\mathbf{F}$ & - & F & $\mathrm{F}$ & A & - \\
\hline Spiniferites spp. undiff. & $\mathbf{R}$ & $\mathbf{F}$ & $\mathbf{R}$ & $\mathrm{F}$ & $\mathbf{R}$ & - & F \\
\hline \multicolumn{8}{|l|}{ P-cysts: } \\
\hline Brigantedinium spp. undiff. & A & $\mathrm{F}$ & A & A & A & A & A \\
\hline Dubridinium caperatum Reid, 1977 & - & $\mathrm{F}$ & $\mathrm{R}$ & $\mathrm{F}$ & $\mathrm{F}$ & $\mathbf{R}$ & - \\
\hline Peridinium faeroense Paulsen, 1905 & $\mathbf{R}$ & C & - & - & - & - & $\mathrm{R}$ \\
\hline $\begin{array}{l}\text { Protoperidinium americanum (Gran } \\
\text { and Braarud, 1935) Balech, } 1974\end{array}$ & $\mathbf{R}$ & - & $\mathrm{R}$ & $\mathrm{R}$ & - & - & 一 \\
\hline $\begin{array}{l}\text { Quinquecuspis concretum (Reid, } \\
\text { 1977) Harland, } 1977\end{array}$ & $\mathrm{R}$ & $\mathrm{R}$ & $\mathrm{R}$ & - & $\mathrm{F}$ & $\mathrm{R}$ & $\mathrm{F}$ \\
\hline $\begin{array}{l}\text { Selenopemphix nephroides Benedek, } \\
1972 \text { emend. Benedek and } \\
\text { Sarjeant, } 1981\end{array}$ & - & - & - & $\mathbf{R}$ & $\mathbf{R}$ & $\mathbf{R}$ & $\mathrm{R}$ \\
\hline $\begin{array}{l}\text { Selenopemphix quanta (Bradford, } \\
\text { 1975) Matsuoka, } 1986\end{array}$ & $\mathrm{R}$ & $\mathbf{R}$ & $\mathrm{F}$ & $\mathrm{F}$ & $\mathrm{F}$ & $\mathrm{F}$ & $\mathrm{C}$ \\
\hline $\begin{array}{l}\text { Trinovantedinium capitatum Reid, } \\
1977\end{array}$ & - & - & - & $\mathbf{R}$ & $\mathrm{R}$ & $\mathbf{R}$ & $\mathrm{F}$ \\
\hline Votadinium calvum Reid, 1977 & $\mathbf{R}$ & - & - & $\mathbf{R}$ & $\mathrm{R}$ & - & $\mathrm{R}$ \\
\hline \multicolumn{8}{|l|}{ Other cysts: } \\
\hline Polykrikos schwartzii Butschli, 1873 & $\mathbf{R}$ & - & - & - & - & - & - \\
\hline Spiny forms & 一 & $\mathbf{R}$ & $\mathrm{F}$ & $\mathbf{R}$ & $\mathrm{F}$ & $\mathbf{R}$ & $\mathbf{R}$ \\
\hline Unidentified form & 一 & $\mathbf{F}$ & - & 一 & - & - & 一 \\
\hline
\end{tabular}

Sample $1=112-686 \mathrm{~B}-1 \mathrm{H}-1,17-39 \mathrm{~cm}(0.30 \mathrm{mbsf}) ; 2=112-686 \mathrm{~B}-1 \mathrm{H}-1,87-96$ $\mathrm{cm}(0.87 \mathrm{mbsf}) ; 3=112-686 \mathrm{~B}-1 \mathrm{H}-3,79-89 \mathrm{~cm}(3.79 \mathrm{mbsf}) ; 4=112-686 \mathrm{~B}-1 \mathrm{H}-5$, $80-90 \mathrm{~cm}(6.80 \mathrm{mbsf}) ; 5=112-686 \mathrm{~B}-3 \mathrm{H}-2,33-45 \mathrm{~cm}(19.83 \mathrm{mbsf}) ; 6=$ 112-686B-9X-5, 30-44 cm (80.08 mbsf); $7=112-686 \mathrm{~B}-15 \mathrm{X}-5,32-42 \mathrm{~cm}$ $(138.32 \mathrm{mbsf}) ; \mathrm{R}=\operatorname{rare}(<3 \%) ; \mathrm{F}=$ few $(3 \%-15 \%) ; \mathrm{C}=$ common $(15 \%-30 \%) ;$ $\mathrm{A}=$ abundant $(>30 \%)$.
Table 11. Dinoflagellate cyst species distribution list for Hole 687B.

\begin{tabular}{|c|c|c|c|c|c|c|c|}
\hline Samples & 1 & 2 & 3 & 4 & 5 & 6 & 7 \\
\hline \multicolumn{8}{|l|}{ G-cysts: } \\
\hline $\begin{array}{l}\text { Nematosphaeropsis labyrinthea } \\
\text { (Ostenfeld, 1900) Reid, } 1974\end{array}$ & $\mathbf{R}$ & $\mathrm{R}$ & - & - & - & 一 & 一 \\
\hline $\begin{array}{l}\text { Operculodinium centrocarpum } \\
\text { (Deflandre and Cookson, 1955) } \\
\text { Wall, } 1967\end{array}$ & - & $\mathrm{F}$ & - & - & - & - & - \\
\hline Spiniferites delicatus Reid, 1974 & $\mathbf{R}$ & - & - & $\mathbf{R}$ & - & - & 一 \\
\hline $\begin{array}{l}\text { Spiniferites mirabilis (Rossignol, } \\
\text { 1963) Sarjeant, } 1970\end{array}$ & - & $\mathbf{R}$ & - & - & - & - & - \\
\hline $\begin{array}{l}\text { Spiniferites ramosus (Ehrenberg, } \\
\text { 1838) Loeblich and Loeblich, } 1966\end{array}$ & $\mathrm{~F}$ & $\mathbf{R}$ & $\mathrm{C}$ & $\mathbf{R}$ & $\mathbf{R}$ & - & $\mathbf{R}$ \\
\hline Spiniferites spp. undiff. & - & $\mathbf{R}$ & - & $\mathbf{R}$ & $\mathbf{R}$ & - & - \\
\hline \multicolumn{8}{|l|}{ P-cysts: } \\
\hline Brigantedinium spp. undiff. & A & A & A & A & A & A & A \\
\hline Dubridinium caperatum Reid, 1977 & $\mathbf{R}$ & $\mathbf{R}$ & - & $\mathbf{R}$ & $\mathbf{R}$ & - & - \\
\hline Peridinium faeroense Paulsen, 1905 & - & $\mathrm{F}$ & - & - & $\mathbf{R}$ & - & - \\
\hline $\begin{array}{l}\text { Protoperidinium americanum (Gran } \\
\text { and Braarud, 1935) Balech, } 1974\end{array}$ & $\mathbf{R}$ & - & $\mathbf{R}$ & - & - & - & - \\
\hline $\begin{array}{l}\text { Quinquecuspis concretum (Reid, } \\
\text { 1977) Harland, } 1977\end{array}$ & $\mathrm{R}$ & $\mathbf{R}$ & - & $\mathbf{R}$ & $\mathbf{R}$ & $\mathrm{F}$ & $\mathrm{F}$ \\
\hline Scrippsiella spp. undiff. & - & - & - & $\mathbf{R}$ & - & - & - \\
\hline $\begin{array}{l}\text { Selenopemphix nephroides Benedek, } \\
1972 \text { emend. Benedek and } \\
\text { Sarjeant, } 1981\end{array}$ & $\mathbf{R}$ & $\mathbf{R}$ & $\mathbf{R}$ & $\mathrm{R}$ & $\mathbf{R}$ & $\mathbf{R}$ & $\mathrm{F}$ \\
\hline $\begin{array}{l}\text { Selenopemphix quanta (Bradford, } \\
\text { 1975) Matsuoka, } 1986\end{array}$ & $\mathbf{R}$ & $\mathbf{R}$ & $\mathbf{R}$ & $\mathrm{F}$ & A & $\mathrm{F}$ & $\mathrm{C}$ \\
\hline Votadinium calvum Reid, 1977 & $\mathbf{R}$ & $\mathbf{R}$ & 一 & - & $\mathbf{R}$ & - & - \\
\hline Votadinium spinosum Reid, 1977 & $\mathrm{R}$ & - & - & $\mathbf{R}$ & - & - & - \\
\hline $\begin{array}{l}\text { Other cysts: } \\
\text { Spiny forms }\end{array}$ & $\mathrm{F}$ & $\mathbf{R}$ & $\mathbf{F}$ & $\mathrm{F}$ & $\mathbf{R}$ & $\mathrm{F}$ & $\mathbf{R}$ \\
\hline
\end{tabular}

Sample $1=112-687 \mathrm{~B}-1 \mathrm{H}-1,38-48 \mathrm{~cm}(0.38 \mathrm{mbsf}) ; 2=112-687 \mathrm{~B}-1 \mathrm{H}-1,79-89$ $\mathrm{cm}(0.79 \mathrm{mbsf}) ; 3=112-687 \mathrm{~B}-1 \mathrm{H}-3,86-98 \mathrm{~cm}(3.86 \mathrm{mbsf}) ; 4=112-687 \mathrm{~B}-3 \mathrm{H}-4$, $38-50 \mathrm{~cm}(19.58 \mathrm{mbsf}) ; 5=112-687 \mathrm{~B}-6 \mathrm{H}-3,111-119 \mathrm{~cm}(47.31 \mathrm{mbsf}) ; 6=$ $112-687 \mathrm{~B}-7 \mathrm{H}-1,62-73 \mathrm{~cm}(53.32 \mathrm{mbs}) ; 7=112-687 \mathrm{~B}-19 \mathrm{X}-3,59-70 \mathrm{~cm}(160.89$ mbsf); $\mathrm{R}=\operatorname{rare}(<3 \%) ; \mathrm{F}=$ few $(3 \%-15 \%) ; \mathrm{C}=$ common $(15 \%-30 \%) ; \mathrm{A}=$ abundant $(>30 \%)$. 


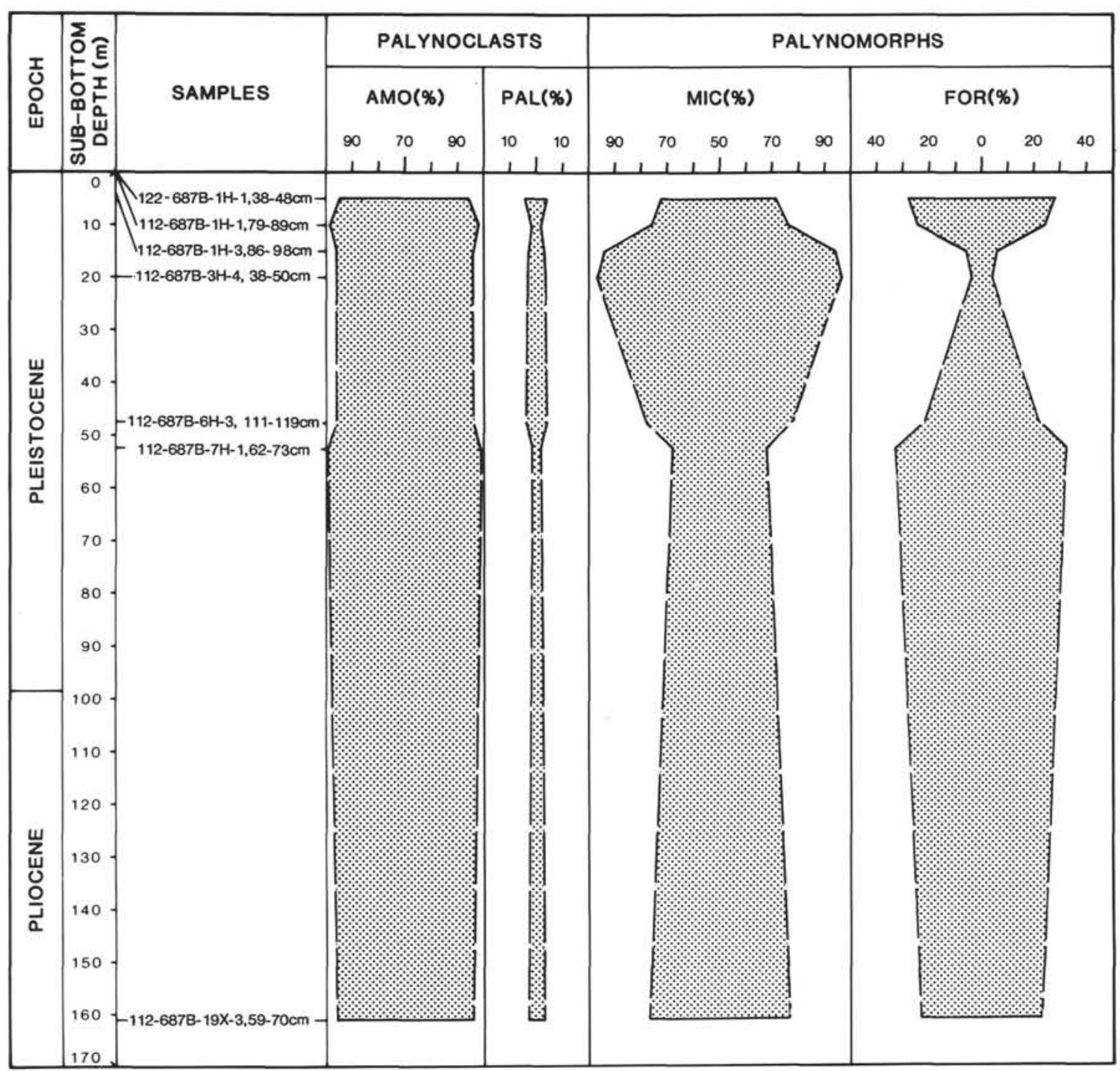

Figure 19. Palynofacies and palynomorph biofacies analysis of Hole $687 \mathrm{~B} . \mathrm{AMO}=$ amorphogen; $\mathrm{PAL}=$ palynomorphs; $\mathrm{MIC}=$ microplankton $; \mathrm{FOR}=$ foraminiferal test linings. 


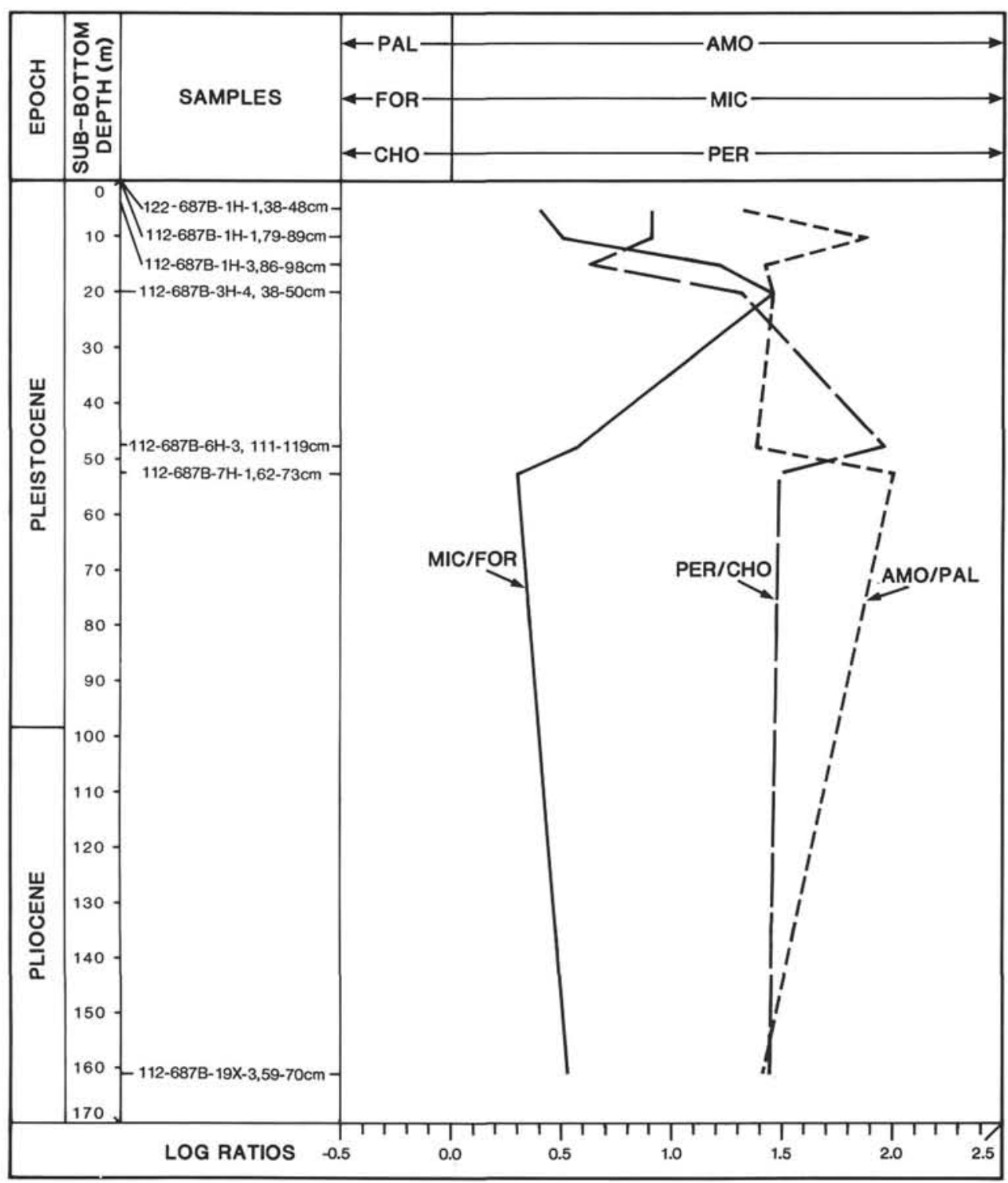

Figure 20. Palynoclast, palynomorph, and microplankton log ratios of Hole 687B. PAL $=$ palynomorphs; $\mathrm{AMO}=$ amorphogen; $\mathrm{FOR}=$ foraminiferal test linings; $\mathrm{MIC}=$ microplankton; $\mathrm{CHO}=$ chorate dinoflagellate (G-cysts); $\mathrm{PER}=$ peridiniacean dinoflagellate cysts (P-cysts); $\mathrm{AMO} / \mathrm{PAL}=$ amorphogen/ palynomorphs log ratio; $\mathrm{MIC} / \mathrm{FOR}=$ microplankton/foraminiferal test linings log ratio; $\mathrm{PER} / \mathrm{CHO}=$ peridiniacean/chorate dinoflagellate cysts (= P-cysts/G-cysts) log ratio. 


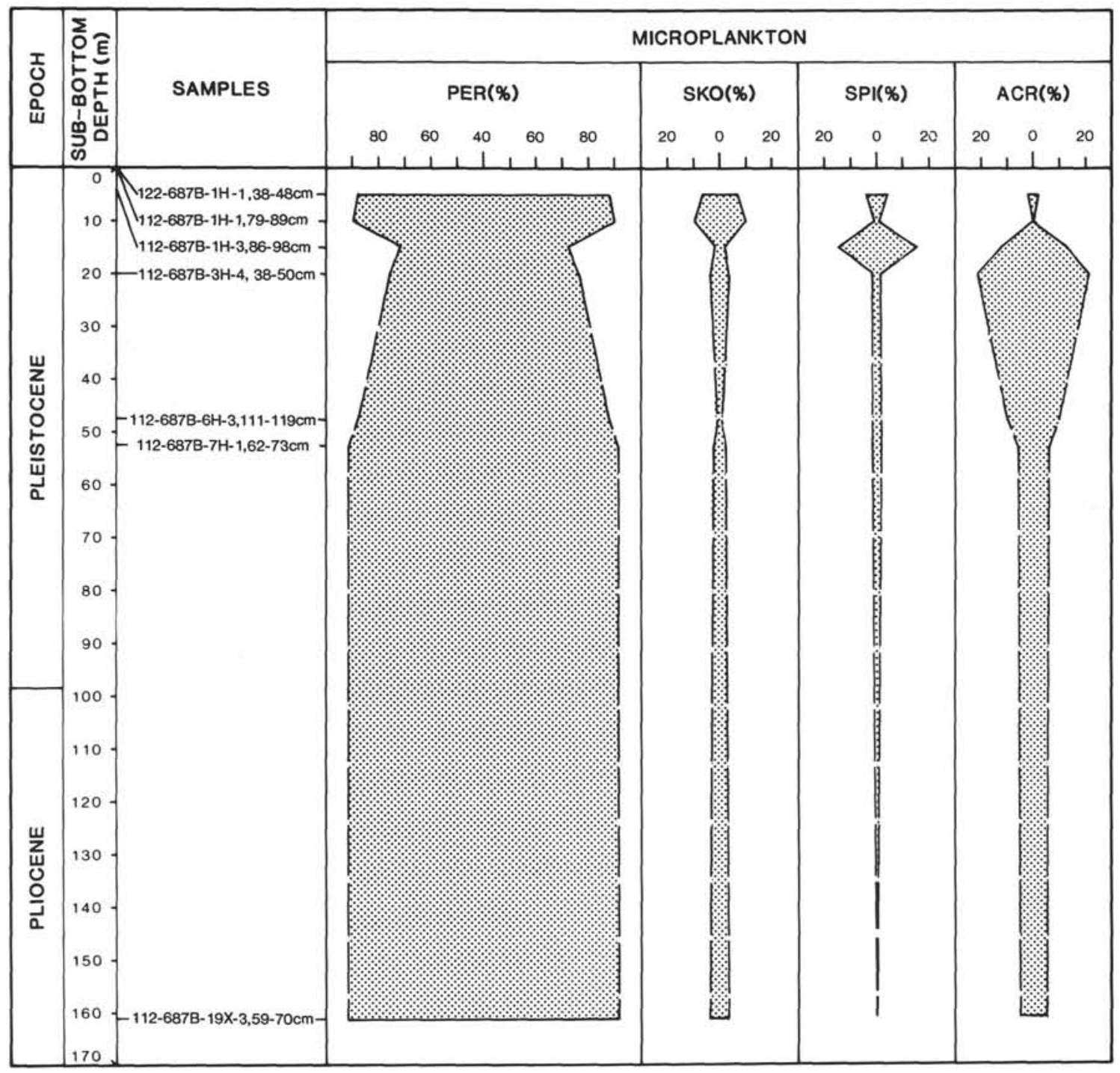

Figure 21. Microplankton biofacies analysis of Hole 687B. PER = peridiniacean dinoflagellate cysts (P-cysts); SKO = skolochorate dinoflagellate cysts (G-cysts); SPI = spiniferate dinoflagellate cysts (G-cysts); ACR = acritarchs. 